

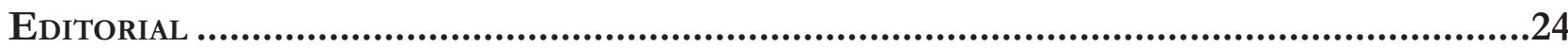

O Direito na fronteira da razão: Psicologia, neurociência e economia comportamental................... 24 Patrícia Perrone Campos Mello e Sergio Nojiri

I. NeURodireito: COGNIÇão, EMOÇÃo, JUÍZOS MORAIS E CIÊNCIA ..........................................26

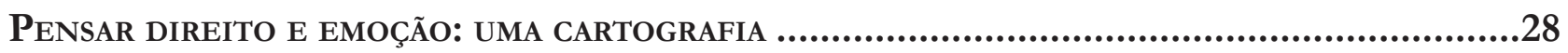

Nevita Maria Pessoa de Aquino Franca Luna

Neurodireito: o início, o fim E O MEIO

Carlos Marden e Leonardo Martins Wykrota

ENSAIO JURÍDICO SOBRE A RACIONALIDADE HUMANA: MAIORES, CAPAZES E IRRACIONAIS

André Perin Schmidt Neto e Eugênio Facchini Neto

DIVERGÊNCIAS DE PRINCÍPIO: ARGUMENTOS JURÍDICOS E MORAIS EM UM CENÁRIO DE DESACORDOS SOCIAIS

André Matos de Almeida Oliveira, Pâmela de Rezende Côrtes e Leonardo Martins Wykrota

CONSILIÊNCIA E A POSSIBILIDADE DO NEURODIREITO: DA DESCONFIANÇA À RECONCILIAÇÃO DISCIPLINAR.....

Thaís de Bessa Gontijo de Oliveira e Renato César Cardoso

MODELOS DE MORALIDADE

Molly J. Crockett

A INFELIZ BUSCA POR FELICIDADE No DiREITo

Úrsula Simões da Costa Cunha Vasconcellost, Noel Struchiner e Ivar Hannikainen

Além da liberdade: PersPeCtivas Em Nietzsche.

Lucas Costa de Oliveira

A mediaÇão de CONFlitos SOb a PERSPECTIVA do DESENVOLVIMENTO HUMANO: AS CONTRIBUIÇÕES DA PSICOLOGIA POSITIVA

Simone de Biazzi Ávila Batista da Silveira e Deise Brião Ferraz

Neuroimagiologia e aValiação de ResPonsabilidade

Nicole A. Vincent 
ANÁLISE CRÍTICA DA ORIENTAÇÃO DE CIDADÃOS COMO MÉTODO PARA OTIMIZAR DECISÕES PÚBLICAS POR MEIO DA TÉCNICA NUDGE.

Luciana Cristina Souza. Karen Tobias França Ramos e Sônia Carolina Romão Viana Perdigão

Políticas públicas e o deVer de monitoramento: “LEVANdo os Direitos A SÉrio". .252 Ana Paula de Barcellos

Nudges E POLÍticas PÚblicas: uM MECANISMO DE COMBATE AO TRABALHO EM CONDIÇÃo ANÁLOGA À DE ESCRAVO .267

Amanda Carolina Souza Silva, Débhora Renata Nunes Rodrigues e Saul Duarte Tibaldi

REDUZINDO A TRIBUTAÇÃO COGNITIVA: LIÇÕES COMPORTAMENTAIS PARA A DIMINUIÇÃO DOS EFEITOS PSICOLÓGICOS ADVERSOS DA POBREZA.............................................................288 Leandro Novais e Silva, Luiz Felipe Drummond Teixeira, Gabriel Salgueiro Soares e Otávio Augusto Andrade Santos

Políticas PÚBLICAS EM SUICÍDIO: DO PATERNALISMO CLÁSSICO AO PATERNALISMO LIBERTÁRIO E NUDGING

Davi de Paiva Costa Tangerino, Gabriel Cabral e Henrique Olive

Nudges COMO POLÍticA PÚbliCA PARA AUMENTAR O ESCASSO NÚMERO DE DOADORES DE ÓRGÃos PARA TRANSPLANTE

Roberta Marina Cioatto e Adriana de Alencar Gomes Pinheiro

Os PROGRAMAS DE INTEGRIDADE PARA CONTRATAÇÃO COM A ADMINISTRAÇÃO PÚBLICA ESTADUAL: NUDGE OU OBRIGAÇÃo LEGAL? UM OLHAR SOBRE AS DUAS PERSPECTIVAS .386

Cíntia Muniz Rebouças de Alencar Araripe e Raquel Cavalcanti Ramos Machado

Paternalismo libertário e Proteção JURídica do AMbiente: POR QUe PROTEger o AMBIENTE TAMBÉM DEVE SER PROTEGER AS LIBERDADES?

Mariana Carvalho Victor Coelho e Patryck de Araujo Ayala

Políticas públicas baseadas EM EVIdÊNCIAS COMPORTAMENTAIS: REFLEXões A PARTIR do Projeto de Lei 488/2017 do Senado

Pâmela de Rezende Côrtes, André Matos de Almeida Oliveira e Fabiano Teodoro de Rezende Lara

III. ECONOMIA COMPORTAMENTAL: VIESES COGNITIVOS E POLÍTICAS PÚBLICAS .455

ECONOMIA COMPORTAMENTAL E DIREITO: A RACIONALIDADE EM MUDANÇA Marcia Carla Pereira Ribeiro e Victor Hugo Domingues

VIESES COGNITIVOS E DESENHO DE POLÍTICAS PÚBLICAS 
A neurociênCia da moralidade na tomada de DeCisões Jurídicas Complexas e No DESENHO DE POLÍTICAS PÚBLICAS

Erik Navarro Wolkart

Desvio de CARÁter ou SIMPLESMENTE HUMANO? ECONOMIA COMPORTAMENTAL APLICADA AO COMPORTAMENTO DESONESTO

Diana Orghian, Gabriel Cabral, André Pinto e Alessandra Fontana

Políticas Públicas e a ConcretizaÇão de direitos sociais: TOMAdA DE DECisão, ARQUITETURA DE ESCOLHAS E EFETIVIDADE

Ana Elizabeth Neirão Reymão e Ricardo dos Santos Caçapietra

BEHAVIORAL ECONOMICS E DIREITO DO CONSUMIDOR: NOVAS PERSPECTIVAS PARA O ENFRENTAMENTO DO SUPERENDIVIDAMENTO .568

Samir Alves Daura

A EDUCAÇÃo FORMAL PARA O CONSUMO É GARANTIA PARA UMA PRESENÇA REFLETIDA DO CONSUMIDOR NO MERCADO? UMA ANÁLISE COM BASE NA BEHAVIORAL LAW AND ECONOMICS (ECONOMIA COMPORTAMENTAL) 600

Marcia Carla Pereira Ribeiro e Edson Mitsuo Tiujo

LIBET, DETERMINISMO E CONSUMO: AS INFLUÊNCIAS DO MARKETING E A RELEVÂNCIA DA DELIBERAÇÃo CONSCIENTE NA SUPERAÇÃo CONDICIONAL DE HÁBITOS DE CONSUMO PERIGOSOS616 Émilien Vilas Boas Reis e Leonardo Cordeiro de Gusmão

CiÊNCIA DO DIREITO TRIBUTÁRIO, ECONOMIA COMPORTAMENTAL E EXTRAFISCALIDADE. .640 Hugo de Brito Machado Segundo

IV. CoMportamento JUdiCiAL: INFLUÊNCIA DE FATORES EXTRAJURÍDicos .660

FATORES METAPROCESSUAIS E SUAS INFLUÊNCIAS PARA A FORMAÇÃo DA DECISÃo JUDICIAL .662 Rogério Roberto Gonçalves de Abreu, Lúcio Grassi de Gouveia e Virgínia Colares

“A VIDA COMO ELA É": COMPORTAMENTO ESTRATÉGICO NAS CORTES Patrícia Perrone Campos Mello

A COMPOSIÇÃo do ÓRGão COLEGIAdo E SEUS EFEITOS NA TOMADA DE DECISÃo .720 André Garcia Leão Reis Valadares

Das 11 ilhas ao centro do arquipélago: os superpoderes do Presidente do STF DURANTE O RECESSO JUDICIAL E FÉRIAS .741 José Mário Wanderley Gomes Neto e Flávia Danielle Santiago Lima 
RAZÃo, EMOÇÃo E DELIBERAÇÃO: AS ADEQUAÇÕES REgIMENTAIS do SUPERIOR TribUNAL DE JUSTIÇA PARA A FORMAÇÃo DE PRECEDENTES EFICAZES

Peter Panutto e Lana Olivi Chaim

Heurística de ancoragem e fiXaÇÃo de danos morais em JUizados especiais Cíveis no Rio DE JANEIRO: UMA NOVA ANÁLISE 778

Fernando Leal e Leandro Molhano Ribeiro

LA PROTECCIÓN DE LOS DERECHOS POLÍTICOS FRENTE A LAS FUNCIONES DISCIPLINARIAS DE LAS AUTORIDADES ADMINISTRATIVAS: SUBSIDIARIEDAD Y DEFERENCIA EN EL SISTEMA INTERAMERICANO DE DERECHOS HUMANOS. Jorge Ernesto Roa Roa

V. A influênCia do gÊNERo no PROCESSO DECisório JUdiCial

Como os Juízes decidem os Casos de estupro? ANALISANDo SENTENÇAS SOb A PERSPECTIVA DE VIESES E ESTEREÓTIPOS DE GÊNERO 826 Gabriela Perissinotto de Almeida e Sérgio Nojiri

GÊNERO E COMPORTAMENTO JUDICIAL NO SUPREMO TRIBUNAL FEDERAL: OS MINISTROS CONFIAM MENOS EM RELATORAS MULHERES?

Juliana Cesario Alvim Gomes, Rafaela Nogueira e Diego Werneck Arguelhes

Hércules, Hermes e a pequena sereia: Uma reflexão sobre estereótipos de gênero, SUbPRESENTAÇÃo DAS MULHERES NOS TRIBUNAIS E (I)LEGITIMIDADE DEMOCRÁTICA DO PODER JUDICIÁRIO .878 Jane Reis Gonçalves Pereira e Renan Medeiros de Oliveira

Prisão Cautelar de gestantes: análise do Fundamento filosófico da decisão do Habeas CoRpus N. 143.641 912

Artur César Souza e Giovania Tatibana de Souza

VI. Neurodireito APlicado ao direito E Ao Processo PENAL....................................926

CÉREbros QUe PUNEM: UMA REVISÃo CRÍTICA DA NEURoCIÊNCIA DA PUNIÇÃo .....................928 Ricardo de Lins e Horta

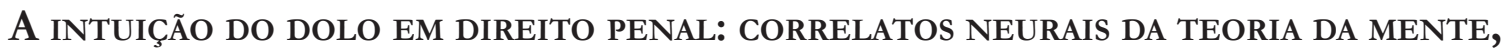
RACIOCÍNIO INDUTIVO E A GARANTIA DA CONVICÇÃO JUSTIFICADA. .946 Thiago Dias de Matos Diniz e Renato César Cardoso

As COMUNIDADES EPISTÊMICAS PENAIS E A PRODUÇÃo LEGISLATIVA EM MATÉRIA CRIMINAL..... 961 Stéphane Enguéléguélé 
DELINQUÊNCIA JUVENIL: RELAÇÕES ENTRE DESENVOLVIMENTO, FUNÇÕES EXECUTIVAS E COMPORTAMENTO SOCIAL NA ADOLESCÊNCIA

André Vilela Komatsu, Rafaelle CS Costa e Marina Rezende Bazon

Límites TEMPORALES A LAS PENAS PRIVATIVAS DE LIBERTAD ATENDIENDO AL DESARROLLO PSICOSOCIAL.

Silvio Cuneo Nash

NEURolaw E AS PERSPECTIVAS PARA UMA ANÁLISE OBJETIVA DO COMPORTAMENTO SUGESTIONADO: REPERCUSSÃO DAS FALSAS MEMÓRIAS NA ESFERA PENAL

Mariana Dionísio de Andrade, Marina Andrade Cartaxo e Rafael Gonçalves Mota

A falibilidade da memória nos Relatos testemunhais: implicaÇões das falsas Memórias NO CONTEXTO DOS CRIMES CONTRA A DIGNIDADE SEXUAL 1036

Caroline Navas Viana

A (IR)REPETIBILIDADE dA PROVA PENAL DEPENDENTE DA MEMÓRIA: UMA DisCUSSÃo COM BASE NA PSICOLOGIA DO TESTEMUNHO. 1058

William Weber Cecconello, Gustavo Noronha de Avila e Lilian Milnitsky Stein 


\title{
A falibilidade da memória nos relatos testemunhais: implicações das falsas memórias no contexto dos crimes contra a dignidade sexual*
}

\author{
The fallibility of memory in witness report \\ the implications of false memories in the \\ context of crimes against sexual dignity
}

Caroline Navas Viana**

\section{Resumo}

Este artigo busca desvendar, pela perspectiva dos estudos sobre Falsas Memórias, a falibilidade dos relatos testemunhais no Processo Penal, em especial nos casos em que a prova oral é aceita como exclusivo meio probatório para a resolução do litígio. Sob o entendimento que a memória humana é falha, estando sujeita ao esquecimento e contaminações, percebeu-se que o relato testemunhal, bem como o reconhecimento de pessoas pela vítima, nem sempre será preciso e fidedigno, estando esses processos sujeitos a erros que podem culminar em desastrosas consequências no Processo; em especial quando se estudam os crimes contra a dignidade sexual, os quais dependem, em grande medida, da prova testemunhal para sua solução. $O$ estudo das Falsas Memórias no Direito se faz indispensável, na medida em que, ao entender o melhor funcionamento do fenômeno, podem ser tomadas atitudes que facilitam a identificação da problemática, bem como medidas que visem à redução dos danos, tornando a prova testemunhal um meio probatório mais seguro. Por essa razão, neste trabalho, por meio de uma pesquisa descritiva e qualitativa do tema, realizou-se um estudo sobre a prova testemunhal, sobre o funcionamento da memória humana e sobre os diversos aspectos que circundam o fenômeno das Falsas Memórias. Tendo constatado a fragilidade do testemunho, sob a ótica da falibilidade da memória, este trabalho se mostra valoroso, sobretudo, enquanto aponta o quão defasado está o tratamento dado a prova testemunhal e quão grave são suas consequências.

Palavras-chave: Falsas memórias. Falibilidade. Prova testemunhal. Crimes contra a dignidade sexual. Testemunha ocular.

* Recebido em 31/05/2018 Aprovado em 10/07/2018

** Advogada graduada em Direito pela Universidade de São Paulo, Campus de Ribeirão Preto, pesquisadora na área de Neurociência aplicada ao Direito, com enfoque em falsas memórias; tendo atuado durante a graduação na Defensoria Pública e na Justiça Estadual de Ribeirão Preto. Email: carol48sjc@hotmail.com

\section{Abstract}

This article seeks to unveil, from the perspective of the studies on False Memories, the fallibility of witness reports in the criminal procedure, especially in cases in which the oral test is accepted as exclusive means of proof for the resolution of the litigation. Under the understanding that human 
memory is flawed, subject to forgetfulness and contamination, it has been realized that the testimonial testimony, as well as the recognition of persons by the victims will not be always accurate and reliable, also these processes are subject to errors that can culminate in disastrous consequences in the procedure; especially when we study crimes against sexual dignity, which rely heavily on testimonial evidence for its solution. The research of the False Memories in the law studies become indispensable, because understanding how does the phenomenon works makes it possible to take measures that facilitate the identification of the problematic, as well as actions focused on the reduction of the damages, making the testimonial evidence as a probative mean more secure. Therefore, in this work, through a descriptive and qualitative research of the subject, a study is carried out on the subjects of testimonial evidence, the functioning of human memory and on the various aspects that surround the phenomenon of False Memories. Having found the fragility of the testimony from the point of view of the fallibility of memory, this work shows its value as it points out how outdated the treatment of the testimonial evidence is and how serious its consequences are.

Keywords: False memories. Fallibility. Testimonial evidence. Crimes against sexual dignity. Eyewitness testimony.

\section{INTRODUÇÃo}

O presente artigo tem como objeto o estudo das implicações das Falsas Memórias no Processo Penal, com enfoque nos impactos desse fenômeno na palavra da testemunha e da vítima em situações nas quais a prova oral é tida como instrumento isolado de prova.

Nesse sentido, a pesquisa proposta neste artigo será voltada à análise das falsas memórias no contexto dos crimes contra a dignidade sexual, uma vez que essa modalidade, em regra, não apresenta materialidade, podendo ocorrer sem a presença de outras testemunhas, a não ser a vítima. Nessa vertente, vislumbra-se um cenário jurídico no qual, para o Processo Penal Brasileiro, a palavra da testemunha é aceita como prova isolada para a confirmação do crime sexual; assim como, na presença de outras provas, a palavra da vítima costuma ter alto valor probatório diante do livre convencimento do Juiz. Em ambos os casos, a prova testemunhal tem o poder de sozinha convencer o Magistrado a se posicionar favorável à condenação.

Todavia, em contramão ao pensamento jurídico consolidado, a prova testemunhal é um meio probatório extremamente complexo e que demanda uma série de cuidados para não ser eivado. Ao depender da narrativa da testemunha sobre o fato ocorrido ou pelo reconhecimento do suspeito, deposita-se toda segurança jurídica na capacidade de memorização e interpretação da vítima sobre o ocorrido. Ocorre, entretanto, que a memória não é infalível. Ao contrário, ela pode apresentar erros e distorções, comprometendo a fidedignidade das lembranças e, consequentemente, colocando em dúvida a credibilidade da prova testemunhal e do resultado do processo sob uma ótica pouco questionada no Processo Penal.

Nesse sentido, este trabalho procurará, de forma não exaustiva, apontar e esclarecer o que são Falsas Memórias, como elas funcionam, e, principalmente, como influenciam testemunhas e vítimas de maneira a comprometerem o resultado justo do Processo.

\section{Da PROVA teStemunhal COMO MEIO DE PROVA}

Antes de iniciar propriamente a análise sobre as implicações das Falsas Memórias, é imprescindível alguns apontamentos sobre o funcionamento da prova testemunhal no Processo Penal Brasileiro.

A começar pela definição: entende-se por meio de prova todo elemento que pode servir, direta ou indi- 
retamente, à demonstração da verdade que se busca no processo. ${ }^{1}$ Nesse sentido, a palavra da testemunha já é uma figura consolidada no meio jurídico probatório, tanto pela sua importância histórica quanto por ser um dos instrumentos de prova mais requisitados.

Como o próprio nome propõe, esse meio probatório centra-se na figura da testemunha que consiste, por sua vez, na pessoa que depõe em juízo sobre fato criminoso, por ela presenciado, e suas circunstâncias, como também informa sobre a personalidade do agente criminoso, ${ }^{2}$ sempre sob palavra de honra de dizer a verdade do que souber e do que lhe for perguntado.

De acordo com a sistemática processual penal, o testemunho é regido, primordialmente, por três princípios: a oralidade, a retrospectividade e a objetividade.

O princípio da oralidade é extraído, diretamente, dos artigos 204, 217, 221 e 223 do Código de Processo Penal $^{3}$, pelo qual se entende que o depoimento deverá ser prestado mediante narrativa verbal, ou seja, oralmente, quando, em contato direto com juiz, com as partes e com seus representantes, excetuados os casos expressamente previstos em lei. Acredita-se que a oralidade do testemunho atribui legitimidade ao discurso, auxiliando o convencimento social que, quando se harmoniza com o convencimento do juiz julgador, constitui sua força, prestígio e eficácia moralizadora. ${ }^{4}$

A retrospectividade, por sua vez, determina que a testemunha seja chamada em juízo para reproduzir fatos passados conhecidos, e não para aventurar-se em fazer previsões futurísticas. Com base nos registros que ficam memorizados em sua mente, a testemunha realiza esses relatos retrospectivos, cabendo ao magistrado o exercício da atividade recognitiva. ${ }^{5}$

Por fim, a objetividade centra-se na ideia de que a testemunha não poderá manifestar no relato dos fatos suas opiniões pessoais, se não em circunstâncias em que tais perspectivas forem inseparáveis, conforme artigo 213 do Código de Processo Penal ${ }^{6}$. Não cabe, portanto, a esta emitir seu juízo de valor sobre o ocorrido, devendo atrelar seu discurso somente aos fatos percebidos por seus sentidos e pertinentes ao objeto da demanda.

Em consonância com esses termos, entende-se por testemunha a pessoa comprometida a dizer a verdade, frente a conhecimento de fato juridicamente relevante, de forma a corroborar a constituição da verdade, agindo sob o compromisso de estar sendo imparcial e dizendo a verdade. ${ }^{7}$

Ocorre, entretanto, que a objetividade da testemunha e a finalidade do relato testemunhal não está isenta de severas críticas. Quando outras áreas do saber são consideradas, percebe-se que o testemunho é uma prova altamente dependente da recordação de fatos, vinculados à capacidade de memorização de quem os narra. Muito se exige da habilidade de recordação da testemunha, a qual tem que descrever com clareza e detalhes um momento que provavelmente foi vivenciado sob forte emoção e de maneira extraordinária; não se levando em consideração a possibilidade da falibilidade do testemunho. Alerta o qual se intensifica quando se verifica que não existe nenhuma regra processual capaz de determinar até onde as testemunhas merecem crédito para terem sua memória e palavras levadas em consideração como instrumento probatório.

1 ISHIDA, Válter Kenji. Processo penal: de acordo com a reforma processual penal. São Paulo: Atlas, 2009. Disponível em: <https://www.passeidireto.com/arquivo/18046231/valter-kenji-ishida---processo-penal---1-edicao---ano-2009>. Acesso em: 10 jul. 2017. p. 113.

2 ISHIDA, Válter Kenji. Processo penal: de acordo com a reforma processual penal. São Paulo: Atlas, 2009. Disponível em: <https://www.passeidireto.com/arquivo/18046231/valter-kenji-ishida---processo-penal---1-edicao---ano-2009>. Acesso em: 10 jul. 2017. p. 131-132.

3 CÉSPEDES, Lívia; ROCHA, Fabiana da (Org.) Vade mecum. São Paulo: Saraiva, 2017. p. 614-615.

4 MALATESTA, Nicola Framarino Dei. A lógica das provas em matéria criminal. Trad.: Paolo Capitanio. Campinas: Bookseller, 2004. p. 326.

5 FLECH, Larissa Civardi. Falsas memórias no processo penal. Disponível em: <https://www.lume.ufrgs.br/bitstream/handle/10183/67291/000872494.pdf?sequence=1>. Acesso em: 20 jul. 2017.

6 CÉSPEDES, Lívia; ROCHA, Fabiana da (Org.) Vade mecum. São Paulo: Saraiva, 2017. p. 614.

7 NUCCI, Guilherme de Souza. Código de Processo Penal Comentado. 8. ed. São Paulo: Revista dos Tribunais, 2008, p. 449. 
Mesmo assim, a prova testemunhal é tida como um dos meios probatórios mais antigos ainda em uso, bem como uma das mais fáceis a ser produzidas comparativamente com outros instrumentos de prova. No Processo Penal, sua utilização é comum, tendo importância considerável no meio, mesmo, pois, não raro, serve como única base para acusações, na ausência de outros meios comprovatórios. ${ }^{8} \mathrm{Caso}$ este muito comum nos chamados crimes contra a dignidade sexual.

\section{DOS CRIMES CONTRA A DIGNIDADE SEXUAL: SUA MATERIALIDADE E COMPROVAÇÃO}

O título VI da parte especial do Código Penal regula os crimes contra a dignidade sexual. Em suma, esse título busca tutelar a liberdade sexual, frisando que é de motivação própria as escolhas das pessoas no tocante ao sexo e ao consentimento de sua prática, em consideração à maturidade da vítima. ${ }^{9}$ Inclusive, a doutrina moderna entende que, no que envolve esses crimes, não há discussão de qualquer aspecto de conotação moral, mas, somente, a preocupação com a proteção com a liberdade sexual da vítima. ${ }^{10} \mathrm{~A}$ intenção, pois, não é o controle da atividade sexual do ser humano, mas, sim, a proteção contra ações que atuem contra a liberdade de exercê-la. ${ }^{11}$

A grande problemática, entretanto, encontra-se na comprovação da ocorrência desse tipo criminal. Uma vez que essa modalidade nem sempre apresenta resquícios materiais para serem utilizados como meio de prova, é admitido que o ato criminoso seja comprovado com base no relato da vítima. Em outras palavras, é permitido que a palavra da testemunha seja utilizada como instrumento isolado de prova nesses processos.

Na prática, a doutrina entende que, nesses tipos de crime, a autoridade e a materialidade são confirmadas pela palavra da pessoa ofendida, cabendo ao juiz analisar a credibilidade da palavra da vítima. ${ }^{12}$ Nos crimes de estupro, por exemplo, entende-se que o testemunho se apresente como viga mestre das provas, devendo a vítima mostrar suas imputações de forma firme, segura e em lógica com os outros fatos comprovatórios do processo para conseguir sustentar a condenação do agressor. ${ }^{13}$

Quando a materialidade está presente, é indispensável a realização de exame de corpo de delito, conforme previsto no artigo 158 do Código de Processo Penal ${ }^{14}$. Mesmo assim, por força normativa do artigo 182 do mesmo código ${ }^{15}$, o juiz possui discricionariedade para ao tomar sua decisão, não ficando adstrito ao laudo desse exame, podendo, inclusive, rejeitá-lo em todo ou em parte, haja vista que ele possui liberdade para valorar as provas ao realizar seu julgamento, sempre motivando seu entendimento.

Ocorre, também, que nem sempre os crimes contra dignidade sexual deixam vestígios ${ }^{16}$, ou, mesmo que deixem, nem sempre são constatados ou coletados. Problema este agravado quando se percebe que o estupro, assim como os outros delitos sexuais, com frequência, é praticado às escuras, geralmente, em locais desabitados ou de difícil acesso, sem a presença de outras testemunhas a não ser a vítima e o real autor. Por esse motivo os crimes contra a dignidade sexual também são chamados de crimes clandestinos, visto que são praticados às escondidas, ao não alcance de testemunhas, com cuidados oportunos à consumação, para não serem desvendados e não deixarem vestígios. ${ }^{17}$ Nessas condições, a palavra da vítima constitui a única fonte

8 ARANHA, Adalberto José Q. T. de Camargo. Da prova no processo penal. 7. ed. São Paulo: Saraiva, 2006. p. 156-157.

9 ISHIDA, Válter Kenji. Curso de direito penal. 2. ed. São Paulo: Atlas, 2009.p. 411-412.

10 GRECO, Alessandra Orcesi Pedro; RASSI, João Daniel. Crimes Contra a Dignidade Sexual. São Paulo: Atlas, 2010 , p. 53.

11 TELES, Ney Moura. Direito Penal: parte especial: arts. 213 a 359-H. 2. ed. São Paulo: Atlas, 2006. p. 3.

12 ISHIDA, Válter Kenji. Curso de direito penal. 2. ed. São Paulo: Atlas, 2009. p. 414.

13 DELMANTO, Celso. Código Penal comentado: acompanhamento de comentários, jurisprudência, súmula em matéria penal e legislação complementar. 8. ed. São Paulo: Saraiva, 2010. p. 695.

14 CÉSPEDES, Lívia; ROCHA, Fabiana da (Org.) Vade mecum. São Paulo: Saraiva, 2017. p. 610.

15 CÉSPEDES, Lívia; ROCHA, Fabiana da (Org.) Vade mecum. São Paulo: Saraiva, 2017. p. 612.

16 CAPEZ, Fernando. Curso de direito penal. 9. ed. São Paulo: Saraiva, 2011. v. 3. p. 38.

17 MUCCIO, Hidejalma. Curso de processo penal. 2. ed. Rio de Janeiro: Método, 2011. p. 913-914. 
que corrobora a acusação do ato, ocorrendo um nítido confronto entre seu discurso, ao se dizer violentada, e o do condenado, que se diz inocente, sem haver consenso para o que realmente aconteceu.

O que hoje muitos magistrados e doutrinadores adotam como um posicionamento frente a casos como este é o dever do magistrado em ter a sensibilidade para apurar se os fatos relatados pela vítima realmente ocorreram, analisando a verossimilhança da narrativa contada, uma vez que se contrapõe com o discurso negativo do acusado. ${ }^{18}$

Acredita-se que a palavra da vítima, coerente e firme, pode basear uma condenação, em especial nesses crimes realizados sem a presença de outros meios probabilísticos comprovados. Sendo tamanha sua relevância, a ponto de poder mudar o destino de um processo criminal. ${ }^{19}$

Para tais análises, os magistrados levam em conta as características da personalidade da pessoa ofendida, seus hábitos e sua ligação com o opressor, dentre outros elementos, sempre sob a maior cautela possível. ${ }^{20}$ Afinal, são necessárias ressalvas na forma como é vista a narrativa acusatória da vítima, cujo conteúdo está carregado de sentimentos humanos como ódio, raiva e paixão, os quais podem distorcer os fatos concretos. Ademais, em relação a esse tipo de depoimento, o ofendido não realiza o juramento de dizer a verdade, podendo, inclusive, mentir em juízo. ${ }^{21}$ Por isso, o julgador aceita tal depoimento com atenção, devendo usar métodos comparativos com outras provas quando possível, posto que a pessoa ofendida se trata de uma parte imparcial cujo interesse está voltado para o desfecho do processo em seu favor. ${ }^{22}$

A verdade é que, na carência de outras comprovações e com o intuito de avaliar a veracidade do relato, o Magistrado, muitas vezes, acaba se valendo de artifícios de valoração que nem sempre atingem o bem desejado, qual seja de perceber o nível de credibilidade do testemunho. Muitas vezes, baseiam-se, simplesmente, na personalidade da vítima e do acusado, bem como em suas aparências sociais. A moça recatada, mais introduzida em valores morais e culturais, tende a ter seu depoimento valorizado com mais estima, principalmente, se comparada a uma moça de má fama, com comportamento sexual fora dos padrões convencionais em que se acredita que, para escapar de mais pressões sobre sua conturbada vida sexual, poderia invocar um estupro como razão para uma gravidez indesejada, por exemplo. ${ }^{23} \mathrm{Ou}$ seja, mesmo demandando o bom senso do juiz, e na análise única de cada caso concreto, muitas vezes tais decisões acabam recaindo em visões estereotipadas do comportamento das pessoas, não revelando o real teor das intenções da vítima.

Assim, em relação a esses tipos criminais, a certeza sobre os fatos é atingida de maneira diferenciada. Quando a materialidade desses crimes não é passível de ser constatada pelo exame de corpo delito ou não sendo realizada tal verificação, a autoria e materialidade são confirmadas nas afirmações do ofendido, pois, de outro modo, seriam condutas criminosas passiveis de impunidade. A certeza, portanto, recai, completa e unicamente, sobre a credibilidade do que é dito e não dito pela vítima a favor da condenação do acusado. Ou, em outras palavras, recai sobre a memória deste a respeito dos fatos ocorridos.

Mas, afinal, será a memória humana tão confiável e infalível a ponto de ser seguro depositar o destino criminal de pessoas na credibilidade do que é lembrado pela testemunha? Para essa e tantas outras dúvidas, o estudo do funcionamento da memória se faz indispensável.

18 GRECO FILHO, Rogério Greco. Curso de direito penal: parte especial. 10. ed. Rio de Janeiro: Impetus, 2013. v. 3. p. 486.

19 GOULART, Valéria Diez Scarance Fernandes. Tortura e prova no processo penal. São Paulo: Atlas, 2002. p. 96.

20 NUCCI, Guilherme de Souza. Código de Processo Penal comentado. 8. ed. São Paulo: Revista dos Tribunais, 2008. p. 952.

21 LOPES JUNIOR, Aury. Direito processual penal e sua conformidade constitucional. 4. ed. Rio de Janeiro: Lúmen Júris, 2009. v. 1. p. 639.

22 TOURINHO FILHO, Fernando da Costa. Processo penal. 30. ed. São Paulo: Saraiva, 2008. v. 3. p. 296.

23 NUCCI, Guilherme de Souza. Código de Processo Penal comentado. 13. ed. Rio de Janeiro: Forense, 2014. Disponível em: <http:// sta.pro.br/livros/19\%20-\%20NUCCI_Guilherme_de_Souza_C\%C3\%B3digo_de_Processo_Penal_Comentado_2014.pdf>. Acesso em: 10 jul. 2017. 


\section{Desmistificando o FUnCIONAMENTO DA MEMÓRIA}

Muito ainda há a se desvendar a respeito do funcionamento da memória e suas dimensões. Entretanto, o estudo da mente vem caminhando em constante evolução e revolucionando a forma como o ser humano se compreende. Nesse sentido, as pesquisas na área vem demonstrando o quanto foram criados mitos desfundados sobre os limites da mente; alguns a subestimando, como outros a superestimando. Nesse sentido, este tópico em diante é, pois, um "grande divisor de caminhos", em que o leitor tem de se preparar para que muitas crenças sejam quebradas a respeito do funcionamento da mente; e aberto a entender a memória e suas dimensões sob uma nova ótica, a qual trabalha com as falhas da mente e busca compreendê-las.

Como um primeiro ponto a ser abordado, diferentemente do que se acredita, a memória não é essencialmente estática. As imagens não conseguem ser armazenadas e evocadas, nos momentos desejados, com tanta perfeição como se imagina.

Sabe-se que a memória se trata de um conjunto de mecanismos psíquicos responsáveis pelo armazenamento de informações e experiências vividas, permitindo sua fixação, retenção e posterior evocação. É a faculdade de reter ideias, impressões e conhecimentos adquiridos. ${ }^{24}$

Em outras palavras, a memória é o meio pelo qual os sujeitos humanos recorrem às suas experiências passadas a fim de utilizar essas informações no presente. Trata-se de um processo de mecanismos dinâmicos associados à retenção e à recuperação da informação. ${ }^{25} \mathrm{~A}$ memória é composta, portanto, pelo registro e gravação de informações, mas também pela lembrança destas, de forma que, no momento de evocação das memórias, o evento recordado não será lembrado com todos os detalhes.

Em consonância com essa visão, a evocação de memórias se assemelha muito mais à ideia de "representação aproximativa", do que a uma reconstrução exata do fato lembrado. ${ }^{26}$ Nas ilustres palavras de Antônio Damásio:

As imagens não são armazenadas sob forma fac-similares de coisas, de acontecimentos, de palavras ou frases. O cérebro não arquiva fotografias Polaroid de pessoas, objetos, paisagens; não armazena fitas magnéticas com música e fala; não armazena filmes com cenas de nossa vida; nem retém cartões com "deixas" ou mensagens de teleprompter do tipo daquelas que ajudam os políticos a ganhar a vida. [...] Se o cérebro fosse uma biblioteca esgotaríamos suas prateleiras à semelhança do que acontece nas bibliotecas. ${ }^{27}$

Quando um fato, um momento, um objeto ou uma pessoa é recordada, o resultado obtido dessa evocação não é uma reprodução idêntica. Trata-se de uma interpretação, oriunda da versão original.

Autores como Altavilla explicam que, no complexo processo de sistematização de uma percepção, é posto em uso o processo associativo, configurando-se com frequência em causas de deformações, acentuadas pelas imperfeições do processo mnemônico. A dinamicidade da memória funda-se na ideia de que a percepção não se fixa em uma imóvel chapa fotográfica, mas, sim, adentra em um órgão primordialmente dinâmico, o qual está sujeito a influências das percepções anteriores, sofrendo um ininterrupto trabalho de deformação que culminam em novas aquisições psíquicas. ${ }^{28}$

Nesse viés, faz-se o primeiro alerta ignorado pelos processualistas: a forma como a testemunha se re-

24 FLECH, Larissa Civardi. Falsas memórias no processo penal. Disponível em: <https://www.lume.ufrgs.br/bitstream/handle/10183/67291/000872494.pdf?sequence=1>. Acesso em: 20 jul. 2017.

25 STERnBerg, R. J. Psicologia cognitiva. Porto Alegre: Artes Médicas Sul, 2000. p. 204.

26 DAMÁSIO, Antônio. O erro de Descartes: emoção, razão e o cérebro humano. Trad. Dora Vicente e Georgina Segurado. 8. ed. São Paulo: Companhia das Letras, 2001. p. 128-129.

27 DAMÁSIO, Antônio. O erro de Descartes: emoção, razão e o cérebro humano. Trad. Dora Vicente e Georgina Segurado. 8. ed. São Paulo: Companhia das Letras, 2001. p. 128.

28 AltaVilla, Enrico. Psicologia judiciária. Tradução de Fernando de Miranda. 2. ed. São Paulo: Livraria Acadêmica Saraiva Editores, 1945. v. 1. p. 34-35. 
corda acerca do fato delituoso não é capaz de ser reconstruída da mesma maneira como o evento ocorreu na realidade. A percepção, seja por um viés filosófico, antropológico ou psicológico, justifica, por si só, a tese da impossibilidade da reconstrução do "todo" como seria o ideal na "busca da verdade" no processo. A existência do processo de tradução ${ }^{29}$ que ocorre entre a realidade das experiências e a formação da memória e, entre esta e posteriormente a evocação, culmina na constante transformação e reconstrução das informações, não transpondo em exatidão a realidade fática tão primordial para um testemunho fidedigno.

Ademais, como uma complementação à dinamicidade da memória, cabe acrescentar que se descobriu que a atividade sensorial e a forma como os fatos são interpretados estão totalmente ligados pela potencialidade na percepção dos estímulos. Em outras palavras, a realidade exterior é compreendida da maneira como os órgãos de sentido a conseguem captar; de modo que, a percepção varia tanto de indivíduo para indivíduo, como também para o mesmo sujeito a depender do momento de sua vida. Nesse sentido a forma como o mundo externo é captado mostra-se, pois, completamente relativa, tendo a percepção do meio maior ou menor potencialidade a variar com as circunstâncias fisiológicas do ambiente, como, por exemplo, enxerga-se melhor de dia e após estar descansado e ouve-se mais precisão à noite. ${ }^{30}$

Também, vincula-se a essa ideia outro aspecto importantíssimo da memória: o processo de esquecimento. Ao contrário do que, durante muito tempo se acreditou, a imensa maioria de tudo aquilo que se aprende ou se vivencia, ou seja, as inúmeras memórias que os indivíduos formam ao decorrer da vida acabam sendo perdidas ou esquecidas. ${ }^{31}$ A memória ao contrário do senso comum não funciona como um gravador ou uma câmera em que qualquer momento é possível recuperar uma lembrança da forma exata como ela ocorreu. ${ }^{32}$ As recordações estão em constante transformação e, com frequência, os fatos vivenciados são esquecidos, mesmo que tenham ocorrido poucos minutos atrás. Esse fenômeno de esquecimento é fisiológico, sendo, sobretudo, uma função adaptativa, na medida em que permite o bloqueio de excesso de informação inútil e a não recordação contínua de momentos dolorosos, humilhantes ou aterrorizantes. ${ }^{33}$

Virgílio trata muito bem dessa relação: ${ }^{34}$

[...] o conteúdo da memória é função da velocidade do esquecimento. Isso quer dizer que a memória é o que resta quando nós esquecemos, e que não há memória sem esquecimento. Porém, a rapidez do esquecimento é mais importante, porque se esquecemos muito rápido, caímos na amnésia, mas se nós não esquecemos ficamos loucos!

Assim, se, por um lado, a memória revela seu teor positivo em evitar que os homens se sintam "aprisionados" em suas lembranças e sentimentos que dela decorrem ${ }^{35}$, por outro, no campo jurídico processual, demonstra a necessidade da coleta de prova em tempo hábil, a fim de que a testemunha não tenha suas lembranças extintas ou viciadas.

29 DI GESU, Cristina. Prova penal e falsas memórias. 2. ed. Porto Alegre: Livraria do Advogado, 2014. p. 108-109.

30 AltaVilla, Enrico. Psicologia judiciária. 2. ed. Tradução de Fernando de Miranda. São Paulo: Livraria Acadêmica Saraiva Editores, 1945. v. 1. p.16-17.

31 IZQUIERDO, Iván. Memória. 2. ed. Porto Alegre: Artmed, 2011. Disponível em: <https://books.google.com.br/books?id=

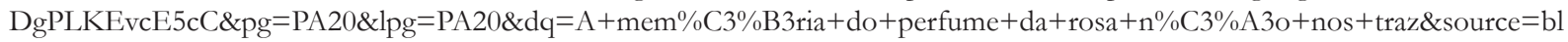
\&ots=-7zWKcMeAf\&sig=1RsAEb4JgImA7aag5RGeLR4wxbI\&hl=pt-BR\&sa=X\&ved=0ahUKEwiTs5Sbz5rVAhWJgZAKHQo 0BFcQ6AEIJzAA\# $=$ =snippet\&q=trabalho\&f=false >. Acesso em: 23 jul. 2017.

32 STEIN, Lilian M. Avanços Científicos em Psicologia do Testemunho Aplicados ao Reconhecimento Pessoal e aos Depoimentos Forenses. Série Pensando o Direito, Brasília, n. 59, 2015.

33 IZQUIERDO, I. $A$ arte de esquecer. 2. ed. Rio de Janeiro: Vieira \& Lent, 2009. v. 1. p.125.

34 VIRILIO, Paul. "O paradoxo da memória do presente na era cibernética". Entrevista com Paul Virilio concedida a Frederico Casalegno. In: Memória cotidiana: comunidades e comunicaşão na era das redes. Entrevista com Paul Virilio concedida a Frederico Casalegno. CASAlEGNO, Frederico. Memória cotidiana: comunidades e comunicação na era das redes. Trad. de Adriana Amaral, Francisco Rüdger e Sandra Montardo. Porto Alegre: Sulina, 2006.

35 IZQUIERDO, Iván. Memória. 2. ed. Porto Alegre: Artmed, 2011. Disponível em: <https://books.google.com.br/books?id= DgPLKEvcE5cC\&pg=PA20\&lpg=PA20\&dq $=\mathrm{A}+\mathrm{mem} \% \mathrm{C} 3 \% \mathrm{~B} 3 \mathrm{ria}+\mathrm{do}+$ perfume $+\mathrm{da}+\mathrm{rosa}+\mathrm{n} \% \mathrm{C} 3 \% \mathrm{~A} 3 \mathrm{o}+$ nos + traz\&source $=\mathrm{bl}$ \&ots=-7zWKcMeAf\&sig=1RsAEb4JgImA7aag5RGeLR4wxbI\&hl=pt-BR\&sa=X\&ved=0ahUKEwiTs5Sbz5rVAhWJgZAKHQo 0 BFcQ6AEIJzAA\# $_{\mathrm{v}}=$ snippet\&q=trabalho\&f=false $>$. Acesso em: 23 jul. 2017. p. 30. 


\section{A EMOÇÃO E O ESQUECIMENTO}

Outro ponto interessantíssimo que, por sua vez, também revela outra problemática para os relatos testemunhais encontra-se na relação da emoção com o esquecimento. É de fé pública que existe uma tendência de os eventos mais marcantes e emocionantes persistirem com mais intensidade e detalhamento na memória. Inclusive, por meio dessa crença, o processo penal se vale, com tanta credibilidade, dos relatos testemunhais das vítimas que passaram por eventos traumáticos; acredita-se que estas, por passarem por momentos de emoção intensa, teriam uma capacidade superior no armazenamento do fato ocorrido, lembrando com melhor qualidade e quantidade de detalhes do que vítimas e testemunhas que não passaram por situações com a mesma carga de sentimentos.

É certo que, logo após o ocorrido, esses acontecimentos marcantes são lembrados com muita riqueza de detalhes. Contudo, a capacidade de o cérebro recordar, por anos ou décadas, um evento com precisão, mesmo em se tratando de um evento marcante com alto teor emocional, trata-se de uma verdadeira crença popular.

O que ocorre, na realidade, é que, realmente, o processo de recordação é facilitado pela emoção. ${ }^{36}$ Contudo, recentes pesquisas apontam que, se, por um lado, existe a tendência de esses eventos emocionais serem recordados com mais facilidade, apresentando um maior índice de memória verdadeira, por outro, existe um aumento proporcional na lembrança de falsas memórias desses eventos. ${ }^{37}$ Em outras palavras, a emoção, realmente, auxilia o processo de recordação, sem entretanto, imunizar esse tipo de lembrança de todos processos de distorções a que a memória está sujeita.

Pesquisas também apontam para os efeitos em níveis extremos de emoção. Embora níveis moderados de emoção potencializam o processo de codificação e, subsequentemente, a performance da memória, percebeu-se que, em níveis extremos, restam prejudicados esses processos de codificação. ${ }^{38} \mathrm{~A}$ forte emoção afeta os processos de cognição e comportamento da pessoa envolvida, em consequência comprometendo a facilidade da recepção e registro de informações. Tanto a falta de atenção como a dificuldade de concentração nesses casos são fatores que afetam, negativamente, o desempenho da memória e, consequentemente, como esses eventos são lembrados.

Os efeitos da emoção na memória não podem ser compreendidos, pois, como uma relação linear, mas sim, curvilínea. Se os níveis de estresse contribuem para a melhoria da memória até certo patamar, acima deste, os efeitos negativos se intensificam, provocando uma piora nas lembranças. ${ }^{39}$

Para piorar o cenário, o cérebro tende a apagar primeiro os detalhes não emocionais. ${ }^{40}$ Ao evocarmos uma lembrança intensa, os detalhes emocionais são constantemente rememorados, enquanto os detalhes periféricos a essas sensações vão se extinguindo, os quais são, justamente, os elementos mais relevantes ao testemunho.

Não existe, nesse viés, uma memória emocional não suscetível a distorções. Tanto as memórias de conotação emocional extremamente negativas como as lembranças de um crime de abuso sexual, até de fatos positivos, de muita felicidade, acabam sucumbindo a esses processos de esquecimento e distorções. ${ }^{41}$

36 STEIN, Lilian M. et al. “Memória, humor e emoção”. Revista de Psiquiatria, Rio Grande do Sul, v. 28, n. 1, p. 66-68, 2006. Disponível em: <http://www.scielo.br/scielo.php?script=sci_arttext\&pid=S0101-81082006000100008>. Acesso em: 8 set. 2017.

37 BRAINERD, C. J. et al. How does negative emotion induce false memories? Psychological science, v. 19, n. 9, p. 919-925, 2008.

38 DI GESU, Cristina. Prova penal e falsas memórias. 2. ed. Porto Alegre: Livraria do Advogado, 2014. p. 113.

39 STEIN, Lilian M. et al. “ Memória, humor e emoção”. Revista de Psiquiatria, Rio Grande do Sul, v. 28, n. 1, p. 66-68, 2006. Disponível em: <http://www.scielo.br/scielo.php?script=sci_arttext\&pid=S0101-81082006000100008>. Acesso em: 8 set. 2017. 40 IZQUIERDO, Ivan. A memória. Entrevisyta com Ivan Izquierdo concedida à RAN - Revista Argentina de Neurociência, por Ignacio Brusco, MD; Diego Golombeck, Phd e Sérgio Strejilevich, MD. Trad. Renato M. E. Sabbatini. Disponivel em: < http:// www.cerebromente.org.br/n04/opiniao/izquierdo.htm >. Acesso em: 23 jul. 2017. p. 5.

41 KENSINGER, E. A., \& SHACTER, D. L. When the red sox shocked the yankees: comparing negative and positive memories. 
Trazendo esses fatos para a seara criminal, avista-se uma grande problemática. Seja moderado ou intenso, o crime, sem dúvida, gera um nível de emoção para aquele que é testemunha ou aquele que é vítima. De forma que, a tendência da memória é de guardar a emoção do acontecimento, a sensação que o evento produziu, em compromisso do que seria mais importante a ser relatado no processo, ou seja, a memória cognitiva, provida de detalhes técnicos e despida de contaminação (emoção, distorção, esquecimento, subjetivismo e juízo de valor. $)^{42}$

\section{Da FORMAÇÃo dAS FALSAS MEMÓRIAS}

Conforme o que já foi explicado, pode-se afirmar que a memória advém tanto das informações armazenadas quanto dos novos elementos que vão se agregando a essas informações ao decorrer do tempo. Nesse sentido, numa analogia, a memória não funciona como ler um livro; mais sim, como escrever um livro com base em anotações fragmentadas. ${ }^{43}$ Ao serem evocadas, as lembranças estão sujeitas a processos de interpretação, de integração ou de supressão de $\operatorname{dados}^{44}$, fato que torna cada experiência lembrada, única.

Diante desses aspectos e de tantos outros que atuam no processo mnemônico, não raras vezes, essas lembranças vão ganhando traços distorcidos, culminando numa falsificação da lembrança, ou, o que hoje se conhece por Falsas Memórias.

De forma sucinta, as Falsas Memórias ocorrem como resultado das distorções externas ou endógenas, ou seja, por indução de terceiros ou por recriação do próprio indivíduo, os mecanismos de aquisição, retenção ou recuperação falham, trazendo o sujeito ao erro. ${ }^{45}$ Em outras palavras, as Falsas Memórias caracterizam-se por serem lembranças de fatos, lugares, pessoas, e eventos que nunca ocorreram ou que ocorrem de forma diversa, em decorrência das transformações naturais que a memória humana sofre nesses processos mnemônicos.

Os estudos das Falsas Memórias são importantíssimos, nesse sentido, uma vez que o fenômeno faz parte do dia a dia das pessoas, decorrente do funcionamento saudável da mente, não se tratando de uma patologia ou distúrbio. ${ }^{46}$ Como um fenômeno que ocorre diariamente, muitas vezes passa despercebido, não trazendo consequências severas para o cotidiano das pessoas. Em contrapartida, em áreas como a jurídica, o não reconhecimento da problemática traz consequências drásticas.

Impera salientar que as Falsas Memória não se confundem com a mentira ou com fantasias criadas pelas pessoas. As Falsas Memória são extremamente semelhantes a memórias verdadeiras, tanto em sua base cognitiva quanto neurobiológica, se diferenciando, somente, pela sua composição, formada no todo ou em parte, por lembranças de informações ou de eventos que não ocorreram na realidade. ${ }^{47}$ Até mesmo o usuário de falsas lembranças não consegue diferenciá-las de um discurso mentiroso, pois, apesar da a mentira ser um ato consciente, em que a pessoa tem noção do seu espaço de criação e manipulação, nas Falsas Memórias, o agente crê sinceramente na verdade que está relatando, não se dando conta de que o que fala é tão falso

Psychonomic Bulletin \& Review, v. 13, n. 5, p. 757-763, 2006.

42 DI GESU, Cristina. Prova penal e falsas memórias. 2. ed. Porto Alegre: Livraria do Advogado, 2014. p. 114.

43 KIHLSTROM, J. F. Exbumed memory. New York: Guilford, 1998. p. 33.

44 LOPES JÚNIOR, Aury. Direito processual penal e sua conformidade constitucional. 8. ed. Porto Alegre: Lumen Juris, 2011. v.1. p. 665.

45 FLECH, Larissa Civardi. Falsas memórias no processo penal. Disponível em: <https://www.lume.ufrgs.br/bitstream/handle/10183/67291/000872494.pdf? sequence=1>. Acesso em: 20 jul. 2017.

46 NEUFELD, Carmem Beatriz; BRUST, Priscila Goergen; STEIN, Lilian Milnitsky. Compreendendo o Fenômeno das Falsas Memórias. In: STEIN, Lilian Milnitsky et. al. Falsas memórias: fundamentos científicos e suas aplicações clínicas e jurídicas. Porto Alegre: Artmed, 2010. p. 37.

47 NEUFELD, Carmem Beatriz; BRUST, Priscila Goergen; STEIN, Lilian Milnitsky. Compreendendo o Fenômeno das Falsas Memórias. In: STEIN, Lilian Milnitsky et. al. Falsas memórias: fundamentos científicos e suas aplicações clínicas e jurídicas. Porto Alegre: Artmed, 2010. p. 36. 
como se uma mentira fosse. ${ }^{48}$

Uma das grandes problemáticas enfrentadas trata-se de os juristas se limitarem a reconhecer o erro voluntário ou mentira como o único mal dos testemunhos, inclusive, tipificando e castigando a conduta, conhecida como falso testemunho, por lei. ${ }^{49}$ Apesar de ambos serem perigosos para a credibilidade da prova testemunhal, as Falsas Memórias são mais graves, na medida em que a testemunha ou vítima desliza no imaginário sem se dar conta disso, fato que dificulta sua identificação no processo. ${ }^{50}$

\section{Os eXPerimentos de Elizabeth Loftus}

No caminho para a compreensão das Falsas Memórias, é praticamente impossível não se deparar com as contribuições feitas pela pesquisadora Elizabeth Loftus. Ao decorrer das mais de quatro décadas de pesquisas, Elizabeth Loftus conseguiu se consolidar como a maior autoridade no cenário dos estudos das Falsas Memórias, estabelecendo o que se entende hoje pelo fenômeno.

A autora conduziu pesquisas e experimentos com mais de 20 mil pessoas, a fim de constatar a ocorrência do fenômeno quando os indivíduos entram em contato com dados não verdadeiros. Como resultado de seus estudos apresentou o entendimento de que as lembranças podem ser altamente manipuladas com base em informações errôneas sobre momentos nunca vividos ${ }^{51}$, bem como podem distorcer os acontecimentos realmente vivenciados.

Constatou, também em suas pesquisas, que a desinformação é um fator modificativo em potencial das lembranças, alterando-as, seja de maneira previsível até mesmo espetacular, nas situações mais cotidianas ${ }^{52}$. Ou seja, as pessoas estão sujeitas a terem informações erradas se imiscuindo em suas lembranças a todo instante, seja em uma conversa com outra pessoa, em um processo interrogativo realizado de forma sugestiva, em uma leitura de jornal e até mesmo quando se assiste a uma reportagem na televisão. ${ }^{53}$

Loftus destaca o quanto essas falsas memórias tomam a dimensão de verdade na cabeça do indivíduo. Tratam-se de memórias embelezadas de detalhes, que se assemelham em todos os pontos com uma memória verdadeira ${ }^{54}$.

Nesse sentido, vale citar de forma exemplificativa, o clássico teste de Loftus e Palmer, o qual comprovou que somente pela troca de uma palavra específica em uma pergunta feita aos participantes, pode-se culminar no surgimento de falsas lembranças, corroborando a tese do poder de sugestão no relato testemunhal. Nesse experimento, os pesquisadores recrutaram voluntários para assistirem a um curto vídeo de um acidente de trânsito envolvendo cinco carros. A seguir, os participantes foram divididos em grupos para responderem a uma pergunta relativa a cena que tinham visto. A pergunta consistia em determinar a velocidade dos carros no acidente, com a diferença que para cada grupo modificou-se uma palavra na pergunta direcionada aos pesquisados. Para uma turma questionou-se à que velocidade circulavam os carros quando estes "se encontraram"; para outro, quando "toparam"; no seguinte, quando "bateram"; e no último, quando "se estraçalharam". Por fim perguntaram se havia a presença de sangue e vidros quebrados. Surpreendentemente todos os entrevistados terem assistido ao mesmo vídeo do acidente e serem questionados após a mesma

48 LOPES JÚNIOR, Aury. Direito processual penal e sua conformidade constitucional. 8. ed. Porto Alegre: Lumen Juris, 2011. v. 1. p. 658. 49 DI GESU, Cristina. Prova penal e falsas memórias. 2. ed. Porto Alegre: Livraria do Advogado, 2014. p. 130-131.

50 LOPES JÚNIOR, Aury. Direito processual penal e sua conformidade constitucional. 8. ed. Porto Alegre: Lumen Juris, 2011. v. 1. p. 658.

51 LOFTUS, Elizabeth. "As falsas lembranças". Revista Viver Mente \& Cérebro, p. 90-93, 2005. p. 90.

52 DI GESU, Cristina. Prova penal e falsas memórias. 2. ed. Porto Alegre: Livraria do Advogado, 2014. p. 133.

53 LOFTUS, Elizabeth. “As falsas lembranças”. Revista Viver Mente \& Cérebro, p. 90-93, 2005.p. 90

54 NEWS, CBN. Exclusive: The bunny effect. Youtube, 8 mar. 2009. Disponível em: <https://www.youtube.com/ watch?v=eZIPzSeUDDw>. Acesso em: 29 jul. 2017. 
quantidade de tempo transcorrido, as respostas foram extremamente diversificadas a depender do tipo de perguntas que lhes foram direcionadas. Quando questionados acerca da velocidade em que os carros estavam no momento em que "se encontraram" a velocidade média obtida das respostas foi de $35 \mathrm{~km}$ por hora, e que não havia vidros quebrados, nem sangue na cena. Para aqueles em que foi perguntada a velocidade dos carros no momento em que "toparam", foram apontadas velocidades mais altas, vidro quebrado, e ausência de sangue. Aqueles que receberam a palavra "bateram" relataram que os carros estavam em velocidade alta, possivelmente entre 60 e $85 \mathrm{~km}$ por hora, com a presença de vidros quebrados e, em alguns casos, sangue. O último grupo, quando questionado sobre a maneira como os carros se "estraçalharam", indicaram velocidades altíssimas, vidros quebrados, sangue, e até pessoas mortas. ${ }^{55}$

Em que pese parecer surreal, não há, neste artigo, o intuito em se desacreditar a prova testemunhal, ante sim, apontar todo o cuidado e ressalvas que devem ser feitos a esse instrumento probatório. O Processo Penal está intimamente ligado com essa problemática, principalmente quando a declaração da vítima e da testemunha forem a única prova acusatória existente. O ponto essencial é perceber que, embora haja o desejo de se desvendar o que realmente aconteceu, a fim de se solucionar o litígio, é necessária uma análise minuciosa quanto à declaração da testemunha, em especial nos casos em que ela figurar como elemento probatório isolado. O induzimento realizado pelos parentes, amigos, policiais, entrevistadores, julgadores, até mesmo pela mídia, em casos notórios, compromete a forma como o crime é lembrado e como ele será relatado. Diante disso, é preciso perceber que, além da deficiência na coleta de provas materiais, constata-se um despreparo pelos profissionais jurídicos para saber identificar e lidar com as falsas memórias, inclusive, no sentido de entenderem que, a depender do grau de contaminação, a palavra da vítima não é suficiente para derrubar a presunção de inocência do acusado. ${ }^{56}$

\section{A PROVA TESTEMUNHAL COMO MEIO ISOLADO DE PROVA}

Infelizmente, no âmbito da Justiça Estadual a prova pericial e os demais instrumentos probatórios são muito pobres, devido à falta de recursos disponíveis para as investigações do caso, tornando-a despida de recursos que lhe confeririam uma melhor qualidade técnica. Esses fatos tornam a prova testemunhal, reconhecida por ser de baixo custo financeiro e de rápido acesso, a prova mais fácil e mais utilizada para a resolução de litígios, nesses tipos de caso. ${ }^{57}$

Daí a necessidade, da prova oral ser colhida e utilizada com a maior cautela possível, uma vez que, se tamanha responsabilidade é depositada nesse tipo probatório, não podem ser negligenciados os cuidados que devem ser tomados frente a todas as problemáticas envolvidas nesse meio. A preocupação do Direito em averiguar e punir os depoimentos mentirosos, enquadrados como falsos testemunho, demonstra o quão ciente e alerta o sistema processual está quanto às consequências gravíssimas frente a um relato não verdadeiro; porém, por outro lado, revela o quanto o Direito está defasado por acreditar que a mentira consciente trata-se do maior desafio a ser superado na prova oral, não sabendo lidar com o falso testemunho sob outras perspectivas, inclusive no que concerne a testemunhas vítimas de falsas memórias.

Nos Estados Unidos, segundo estimativas feitas ao final da década de 1980, a cada ano, mais de 75 mil julgamentos de crimes são decididos embasados na prova testemunhal. Em estudo recente, no qual utilizou-se a análise do DNA para comprovar a inocência de condenados injustamente, percebeu-se que, dentre 40 dos acusados analisados, 36 deles, ou seja, 90\% do total, tinham sido presos pela identificação errada realizada pelas testemunhas no ato de reconhecimento. ${ }^{58}$

55 IZQUIERDO, I. A arte de esquecer. 2. ed. Rio de Janeiro: Vieira \& Lent, 2009. v. 1. p. 140.

56 DI GESU, Cristina. Prova penal e falsas memórias. 2. ed. Porto Alegre: Livraria do Advogado, 2014. p. 135.

57 DI GESU, Cristina. Prova penal e falsas memórias. 2. ed. Porto Alegre: Livraria do Advogado, 2014. p. 161.

58 SCHACTER, Daniel. Os sete pecados da memória: como a mente esquece e lembra. Rio de Janeiro: Rocco, 2003. p. 118. 
Infelizmente, por mais que tenham sido desenvolvidas outras técnicas, dados mais atuais demonstram que o uso do relato testemunhal como prova única ou principal para a condenação continuam a produzir em massa incriminações injustas, principalmente quando se analisam os julgamentos de crimes contra a dignidade sexual. Nesse sentido, dados fornecidos pelo Innocence Project, um projeto no qual, por meio de trabalho pro bonu, elaboram recursos contra decisões de tribunais e fazem pedidos de reabertura de casos onde exista a possibilidade de inocência de pessoas condenadas, demonstram que de 195 casos em que foi conseguida a exoneração, 148 deles tratavam-se de crimes sexuais, e, por sua vez, dos 148, em 103 deles foram comprovados a ocorrência de falso reconhecimento como causa principal da condenação. Isto representa um porcentual de erro de mais de $69 \% .{ }^{59}$

Dados como estes alertam o quanto as Falsas Memórias e os outros erros e distorções a que a mente está sujeita são fontes de influência para o processo penal, tornando-se inestimável as consequências para as partes quando o estudo desses impactos e possíveis soluções são renegadas no meio jurídico.

\section{Do RECONHECIMENTO PESSOAL CONDUZIDO SEM A OBSERVÂNCIA DAS FORMALIDADES LEGAIS}

Em que pese o processo penal tente regular o ato de reconhecimento, existem muitas lacunas e falhas no modo como é conduzido pelas autoridades na prática; de forma que são, na grande maioria dos casos, desconsideradas variáveis, como as próprias falsas memórias, ainda que estejam a todo instante interferindo nesses processos.

Sabendo-se que, no processo de reconhecimento, a testemunha é levada a perceber alguma coisa, imagem esta que acaba sendo comparada com o que havia realmente percebido no contexto do litigio, ${ }^{60}$ nota-se que a percepção humana é o fator-chave ao se reconhecer o agressor.

Como a percepção humana se aprimora por meio da repetição, tornando-se mais precisa e complexa; uma imagem consegue ser evocada com mais detalhes e distinguida entre seus pares, quando já se tem um conhecimento prévio e consolidado acerca do objeto ou da pessoa lembrada. ${ }^{61} \mathrm{Em}$ outras palavras, uma imagem se torna mais nítida proporcionalmente ao número de vezes que é rememorada em um certo período de tempo. Portanto, no processo de reconhecimento, é imprescindível o cuidado para que a imagem do suspeito fornecida pelas autoridades não seja "metralhada" à vítima de forma a se sobrepor a imagem do real agressor.

É esse um ponto crucial, que passa muitas vezes despercebido nos tribunais: a certeza da testemunha sobre quem está reconhecendo não necessariamente está ligada com a verdade, ante sim, está relacionada com a percepção que foi se tornando mais precisa pelas evocações continuas da imagem do possível suspeito. Suspeito que não necessariamente é o autor do crime, tratando-se, muitas vezes, de um inocente que, em decorrência de alguma sugestão no processo de reconhecimento, fez com que a testemunha imiscuísse sua imagem com a do verdadeiro criminoso, e passasse a recorda-la no lugar deste, até se tornar uma certeza.

Um caso desse tipo foi apontado por Stein e Neufeld ${ }^{62}$ :

Chamado para fazer uma corrida, um taxista foi vítima de um assalto, no qual sofreu ferimentos e foi levado ao hospital. O investigador do caso mostrou ao taxista, que ainda estava em fase de recuperação,

59 INNOCENCE Project. Disponíveis em: <https://www.innocenceproject.org/all-cases/\#involved-yes, exonerated-bydna,sex-crimes >. Acesso em: 31 maio. 2018.

60 CORDERO, Franco. Procedimiento penal. Trad.: Jorge Guerrero. Santa Fé de Bogotá- Colômbia: Editorial Temis, 2000. v. 2. p. 106.

61 DI GESU, Cristina. Prova penal e falsas memórias. 2. ed. Porto Alegre: Livraria do Advogado, 2014. p. 162.

62 NEUFELD, Carmem Beatriz; BRUST, Priscila Goergen; STEIN, Lilian Milnitsky. Compreendendo o Fenômeno das Falsas Memórias. In: STEIN, Lilian Milnitsky et. al. Falsas memórias: fundamentos científicos e suas aplicações clínicas e jurídicas. Porto Alegre: Artmed, 2010. p. 22. 
duas fotografias de suspeitos. O taxista não reconheceu os homens apresentados nas fotos como sendo algum dos assaltantes. Passados alguns dias, quando foi à delegacia para realizar o reconhecimento dos suspeitos, ele identificou dois deles como sendo os autores do assalto. Os homens identificados possivelmente eram aqueles mesmos das fotos mostradas no hospital. Os suspeitos foram presos e acusados pelo assalto. Ao ser questionado em juízo sobre seu grau de certeza de que os acusados eram mesmo os assaltantes, o taxista declarou: 'eu tenho mais certeza que foram eles, do que meus filhos são meus filhos!' Todavia, alguns meses depois, dois rapazes foram presos por assalto em uma cidade vizinha, quando interrogados, confessaram diversos delitos, incluindo o assalto ao taxista.

Percebe-se, com base no caso exposto, que a recordação do taxista sofreu distorções por conta de seu contato com as fotos, fazendo com que a imagem do rosto dos rapazes das fotografias substituísse a lembrança dos verdadeiros autores, fato que culminou na incriminação de dois inocentes.

Na fase pré-processual, é normal a apresentação de fotografias dos supostos suspeitos à vítima, como um ato preparatório de reconhecimento, inclusive, com o intuito de se dar maior legitimidade e credibilidade à identificação. ${ }^{63}$ Ato este que acaba em alguns casos influenciando a vítima a qual crê que a polícia, na posição de figura de autoridade e experiente na solução de casos, somente realizaria um ato de reconhecimento se já tivesse um suspeito de peso. ${ }^{64}$ Dessa maneira, mesmo na dúvida, o crédito na polícia e a vontade de se fazer justiça acabam contribuindo para a indução a uma falsa lembrança.

Ocorre que o reconhecedor trabalha sobre uma matéria alógica, rodeada de sensações. Na lembrança de um rosto, não existem os mesmos caminhos racionais por meio dos quais se constroem as narrativas de fatos ou eventos passados. A recordação de uma face está muito mais ligada a impressões visuais, que se perdem facilmente na memória, do que a lembranças historicamente elaboradas ${ }^{65}$ Em outras palavras, para uma pessoa de capacidade cognitiva normal, é muito mais difícil a memorização de um rosto que foi visualizado somente uma vez, e, possivelmente, em um curto período, do que rememorar a face de uma pessoa conhecida ou de lembrar uma história, cuja lógica dos fatos contribuem para ser mais facilmente recordada. A evocação da imagem de um rosto depende, sobretudo, da lembrança de detalhes, que, como já demonstrado, são extremamente expostos ao esquecimento e à distorção.

Não bastasse a dificuldade natural, muitas vezes as regras do ato de reconhecimento processual não são obedecidas, podendo surgir contaminações em decorrência desses erros procedimentais. Como determina o artigo 226 do Código de Processo Penal ${ }^{66}$, cabe a pessoa que faz o reconhecimento descrever a pessoa a ser identificada, para, a partir desses dados, serem selecionados possíveis suspeitos que tenham as mesmas características físicas a fim de que a vítima aponte, caso esteja no grupo, o autor do crime.

Todavia as regras sejam claras, nem sempre os suspeitos apresentados, seja no reconhecimento fotográfico como no pessoal, são semelhantes fisicamente, induzindo a vítima a reconhecer a figura do autor naquele único suspeito mostrado que coincida com a descrição feita. Bem como, acontece de a vítima não ser bem instruída no sentido de não se sentir pressionada a reconhecer o criminoso dentre os suspeitos trazidos, haja vista que nem sempre dentre os sujeitos mostrados encontra-se o autor do fato. ${ }^{67}$

A não obrigatoriedade da aplicação dos procedimentos determinados pelo artigo 226, somado à falta de sanções em caso de descumprimento das regras, bem como à falta de maiores instruções para um procedimento mais seguro, como a determinação do número de participantes que enquadrarão o rol de suspeitos mostrados, tornam ainda mais precário o esquema procedimental. ${ }^{68}$ Isto sem considerar o fato extremamente prejudicial da impossibilidade de, em juízo, se reiterar o ato de reconhecimento na presença das mesmas

63 DI GESU, Cristina. Prova penal e falsas memórias. 2. ed. Porto Alegre: Livraria do Advogado, 2014. p. 164.

64 DI GESU, Cristina. Prova penal e falsas memórias. 2. ed. Porto Alegre: Livraria do Advogado, 2014. p. 165.

65 CORDERO, Franco. Procedimiento Penal. Trad.: Jorge Guerrero. Bogotá: Temis, 2000. v. 2. p. 111.

66 CÉSPEDES, Lívia; ROCHA, Fabiana da (Org.) Vade mecum. São Paulo: Saraiva, 2017. p. 615-616.

67 GIACOMOLLI, Nereu josé. A fase pre-liminar no processo penal: crises, misérias e novas metodologias investigativas. Rio de Janeiro, Lumen Juris, 2011. p. 157-158.

68 DI GESU, Cristina. Prova penal e falsas memórias. 2. ed. Porto Alegre: Livraria do Advogado, 2014. p. 167. 
pessoas apresentadas na fase preliminar, à maneira que somente o acusado será a presença repetida em ambos os casos, contribuindo para o induzimento da vítima ao reconhecê-lo. ${ }^{69}$

Frente a todas essas problemáticas, seria prudente a justiça brasileira parar de se valer do processo de reconhecimento por meio de fotografias discricionárias, atentando-se mais ao livre relato das características do imputado, principalmente quando essas condenações, baseadas em reconhecimento fotográfico ou pessoal, são feitas sem a devida atenção às regras procedimentais. ${ }^{70}$ Os atos formais, apontados em lei, devem ser vistos como obrigatórios e, portanto, respeitados, na medida que como regras já estabelecidas visam a um procedimento de maior qualidade e ajudam a evitar distorções. Afinal, a questão crucial é criar um cenário cujo nível de indução seja o menor possível, em que a polícia tenha o cuidado de não confundir a vítima apresentando-a fotos de suspeitos de forma discricionária, bem como, no reconhecimento pessoal, construir a roda de testemunhas em número e semelhanças suficientes, a fim de que a testemunha identifique por si o suspeito, em vez de ser guiada a ele por erros técnicos, comprometendo todo o propósito do ato de reconhecimento, qual seja conhecer o real agressor. ${ }^{71}$

\section{TEMPO DE COLHEITA DA PROVA TESTEMUNHAL: DO TRANSCURSO DO TEMPO}

Outro ponto de primordial entendimento quando se estudam falsas memórias no contexto jurídico diz respeito ao tempo do processo. A razoável duração do processo, garantida constitucionalmente no artigo $5^{\circ}$, LXXVIII, determina que: "a todos no âmbito judicial e administrativo, são assegurados a razoável duração do processo e os meios que garantam a celeridade de sua tramitação" "72. Essa garantia deve ser entendida sob duas óticas, a primeira a qual se refere a preocupação quanto à demora jurisdicional e a todos os problemas decorrentes da falta de rapidez na tramitação; e a segunda perspectiva, que visa à proteção dos direitos e das garantias das partes, que poderia ser mitigada em decorrência de um processo muito célere. ${ }^{73}$

Em outras palavras, o processo, ao mesmo tempo que não pode ser julgado imediatamente, sem que haja a maturação do ato de julgar e a observância das garantias fundamentais do contraditório, da ampla defesa, da presunção de inocência, da motivação das decisões judiciais, dentre outras mais; ${ }^{74}$ não pode se prolongar, indefinidamente, a ponto de se tornar ineficiente em seu propósito, uma vez que, pelo transcurso prolongado do tempo, podem ocorrer o perecimento das pretensões, danos econômicos e psicológicos às partes e profissionais do Direito, incentivos à composições desvantajosas, e, consequentemente, o descrédito da força Judiciária e do Estado. ${ }^{75}$

O tempo do processo é resultado de regras processuais e da matéria litigiosa, a qual determina o ritmo dos procedimentos. ${ }^{76} \mathrm{Na}$ prática, o tempo de duração do processo aumentou, tendo em vista que a sociedade e as relações que a regem estão evoluindo e se tornando mais complexas, da mesma maneira que o mecanismo estatal está sobrecarregado. O maior acesso ao Judiciário, refletindo em um constante aumento no volume de processos, está gerando seu congestionamento, de forma que a estrutura estatal não está sendo capaz de acompanhar esse aumento na demanda. ${ }^{77}$

69 LOPES JUNIOR, Aury. Direito processual penal e sua conformidade constitucional. 2. ed. Rio de Janeiro: Lúmen Júris, 2007. v. 1. p. 632.

70 DI GESU, Cristina. Prova penal e falsas memórias. 2. ed. Porto Alegre: Livraria do Advogado, 2014. p. 169.

71 LOPES JÚNIOR, Aury. Direito processual penal e sua conformidade constitucional. 8. ed. Porto Alegre: Lumen Juris, 2011. v. 1. p. 674.

72 CÉSPEDES, Lívia; ROCHA, Fabiana da (Org.) Vade mecum. São Paulo: Saraiva, 2017. p. 9.

73 DI GESU, Cristina. Prova penal e falsas memórias. 2. ed. Porto Alegre: Livraria do Advogado, 2014. p. 172.

74 DI GESU, Cristina. Prova penal e falsas memórias. 2. ed. Porto Alegre: Livraria do Advogado, 2014. p. 172-173

75 TUCCI, José Rogério Cruz e. Tempo e processo: uma análise empírica das repercussões do tempo na fenomenologia processual (civil e penal). São Paulo: Revista dos Tribunais, 1997.

76 SPENGLER, Fabiana Marion. Da jurisdição à mediação: por uma outra cultura no tratamento de conflitos. Ijuí: Ed. Unijuí, 2010. p. 212.

77 TUCCI, José Rogério Cruz e. Tempo e processo: uma análise empírica das repercussões do tempo na fenomenologia processual 
A questão do tempo de duração do processo é de grande importância, na medida em que o Estado se caracteriza, principalmente, pela sua função social, tendo como função primordial assegurar o bem comum e realizar a justiça social. ${ }^{78}$ Nesse sentido, não há justiça social quando o Estado, por meio do Poder Judiciário, não sabe lidar em tempo hábil e de forma efetiva com as demandas que lhe são apresentadas. ${ }^{79}$

A prova testemunhal relaciona-se nesse contexto, à medida que a duração do processo afeta, diretamente, a qualidade técnica desse meio probatório. Quando se pensa na prova testemunhal, não se pode esquecer de que o fator temporal afeta, diretamente, a forma como os eventos, pessoas e coisas são lembradas. A memória não funciona como um "HD" de computador, em que os arquivos são abertos e resgatados a um clique. A memória é falha. E o tempo atua o sentido de impulsionar a ocorrência desses erros.

Por isso o transcurso do tempo constitui um fator extremamente prejudicial à acurácia desse tipo probatório, de maneira que será maior a sua confiabilidade se feita dentre de um prazo razoável. Uma vez que a prova testemunhal se baseia na memória das pessoas, não pode ser negligenciado o fator da passagem do tempo na mente; afinal, existe uma tendência ao esquecimento, em que os detalhes dos acontecimentos se desvanecem, bem como tornam-se mais sujeitos a distorções e a sugestões. ${ }^{80}$

Assim como ensinou Gauer, os acontecimentos não são retidos na memória; posto que as imagens não se fixam, acabam escapando pela fluidez da velocidade. ${ }^{81}$ Em outras palavras, a mente não fixa, eternamente, as memórias com exatidão. De quanta credibilidade e valor tem, portanto, uma prova testemunhal feita meses ou anos depois do ocorrido, quando essas lembranças já passaram por inimagináveis processos de distorção?

Ao estudar falsas memórias, entende-se o perigo da situação, muitas vezes despercebido pelo nosso sistema processual atual. Somando isto às supracitadas problemáticas no ato de reconhecimento, temos um cenário jurídico extremamente despreparado para lidar com a problemática. E, mesmo assim, ainda se julgam casos, principalmente os crimes contra dignidade sexual, baseando-se somente no que é dito pela vítima. Vítima que, em regra, passou por processos de entrevista e reconhecimento que não estão devidamente atentos quanto a fatores de contaminação da memória, e que, muitas vezes, teve sua palavra ouvida meses, ou mesmo anos depois do ocorrido, decorrente da longa duração do processo.

Assim, ao se pensar na pretensão do Estado em solucionar o litígio visando aos seus ideais de justiça social, a colheita da prova testemunhal deve ser feita em tempo certo, a fim de que o tempo transcorrido entre delito ao reconhecimento ou ao relato testemunhal não seja extenso o bastante para contaminar a forma como o evento é lembrado, comprometendo o resultado justo do processo. Dessa maneira, o processo não pode se prolongar a ponto de, quando chamada em juízo, a vítima já não se lembre com precisão do ocorrido, vendo-se forçada a lembrar imprecisamente do agressor e dos fatos para a solução do litígio.

(civil e penal). São Paulo: Revista dos Tribunais, 1997.

78 SILVA, Queli Cristiane Schiefelbein da; SPENGLER, Fabiana Marion. Memória e Tempo: a razoável Duração do Processo Pós-Emenda Constitucional no 45/2004. Direito em Debate: Revista do Departamento de Ciências Jurídicas e Sociais da Unijuí, Rio Grande do Sul, v. 12, n. 39, p. 99-121, 2013.

79 RODRIGUES, Horácio Wanderlei. Acesso à Justiça e prazo razoável na prestação jurisdicional. In: WAMBIER, Teresa Arruda Alvin (Org.). Reforma do Judiciário: primeiras reflexões sobre a emenda constitucional n. 45/2004. São Paulo: Revista dos Tribunais, 2005. p. 285.

80 DI GESU, Cristina. Prova penal e falsas memórias. 2. ed. Porto Alegre: Livraria do Advogado, 2014. p. 173.

81 GAUER, Ruth. “Falar em tempo, viver o tempo!”. In. GAUER, Ruth M. Chittó; LINHARES, Mozard (Org). Tempo: história. Curitiba: Juruá, 1999. p. 26. 


\section{RepetiçÃo dAs ENTREVISTAS: DA PROVA TESTEMUNHAL COMO ELEMENTO PROBATÓRIO IRREPETÍVEL}

Apesar do transcurso do tempo agir, normalmente, de forma negativa na memória, favorecendo o esquecimento e a perca gradual de nitidez e detalhes, bem como o aumento de chances do desenvolvimento de falsas memórias, a passagem do tempo não significa, necessariamente, que o processo de esquecimento sempre acontecerá. Isto, porque existem fatores que atuam no sentido de melhorarem a retenção da lembrança, sendo um desses elementos o número de vezes que a pessoa ficou recuperando o evento em sua mente, ou seja, quanta vezes ela relembrou-se do ocorrido ao decorrer do tempo. ${ }^{82}$

Nesse sentido, o processo de recuperação ocorre quando o sujeito pensa ou fala sobre algum evento, forçando a evocação de uma lembrança. Ao evocar uma memória repetidas vezes, existe a tendência de consolidar seu armazenamento. ${ }^{83}$ Por isso, à primeira vista, a repetição de entrevistas aparenta ser benéfica a fidedignidade do que for relatado pela testemunha, uma vez que, ao constantemente relatar o ocorrido, os detalhes serão mais facilmente armazenados e não se sujeitaram ao esquecimento.

Todavia, isto se comprovaria caso se tratasse de um cenário ideal sem interferências. Na realidade, cada vez que uma memória é recuperada, existe o risco de ela ser modificada por sugestões internas e externas, ${ }^{84}$ fazendo com que pela repetição constante da lembrança contaminada, ela seja armazenada com erros e distorções.

A repetição de entrevistas, em virtude desse fator, muitas vezes acaba propagando efeitos danosos à memória. O longo transcurso de tempo entre as entrevistas, somado às induções internas e externas que a testemunha sofre dentro e fora desses processos, oportuniza a contaminação daquilo que a testemunha ou vítima realmente viu ou ouviu, de forma que o contato com outras pessoas e com entrevistadores confunde aquele entrevistado a ponto de não saber identificar aquilo que sabe daquilo que lhe foi falado posteriormente. ${ }^{85}$ Dito isto, percebe-se um fator importantíssimo negligenciado pela justiça brasileira: a prova testemunhal não é repetível.

Ocorre que o sistema atual não atua considerando esses entendimentos, inclusive, é frequente, na maioria dos casos, a repetição de entrevistas com as testemunhas, independentemente do tempo transcorrido e de possíveis contaminações nas lembranças. Assim, mesmo que por força do artigo 155 do Código de Processo Penal $^{86}$, o qual determina que o juiz não pode formar sua convicção somente em informações colhidas na fase da investigação, a não ser que se tratem de provas irrepetíveis; a vítima, mesmo que seja ouvida em data próxima à ocorrência do delito, quando suas memórias ainda estão melhor preservadas, dificilmente terá suas declarações usadas como prova, pois se acredita que, como a entrevista pode ser refeita com a mesma qualidade e fidedignidade nas respostas a qualquer momento, o uso dessa prova produzida em fase pré-processual torna-se inviável.

Essa visão opõe-se totalmente ao que se sabe atualmente sobre o funcionamento da mente e seus limites. O que os estudos têm revelado promovem a ideia da prova testemunhal como uma prova irrepetível, ou seja, impossível de ser novamente realizada, seja pelo fator temporal, que culmina no esquecimento e em distorções das lembranças, seja pelo simples fato de um testemunho não ser igual ao outro. ${ }^{87}$

82 STEIN, Lilian M. Avanços Científicos em Psicologia do Testemunho Aplicados ao Reconhecimento Pessoal e aos Depoimentos Forenses. Série Pensando o Direito, Brasília, n. 59, p. 21-22, 2015.

83 ROEDIGER, Henry L.; KARPICKE, Jeffrey D. Test-enhanced learning taking memory tests improves long-term retention. Psychological Science, v. 17, n. 3, p. 249-255, 2006.

84 CHAN, Jason C. K.; THOMAS, Ayanna K.; BULEVICH, John B. Recalling a witnessed event increases eyewitness suggestibility the reversed testing effect. Psychological Science, v. 20, n. 1, p. 66-73. 2009.

85 DI GESU, Cristina. Prova penal e falsas memórias. 2. ed. Porto Alegre: Livraria do Advogado, 2014. p. 182.

86 CÉSPEDES, Lívia; ROCHA, Fabiana da (Org.) Vade mecum. São Paulo: Saraiva, 2017. p. 609.

87 STEIN, Lilian M. Avanços Científicos em Psicologia do Testemunho Aplicados ao Reconhecimento Pessoal e aos Depoimen- 
Nesse sentido, o grande erro hoje constatado quanto à repetição de entrevistas concentra-se em dois fatos, portanto: na crença de que a prova testemunhal se trata de uma prova que pode ser repetida, inclusive, com a mesma qualidade, independentemente do tempo ou dos métodos empregados na entrevista que for realizada, e que a repetição de entrevistas não é danosa à preservação da prova oral. Dois fatos que poderiam ser superados, com o material de estudo e pesquisa já existentes sobre o tema.

\section{SUBJETIVISMO DO JULGADOR: A IMPARCIALIDADE E NEUTRALIDADE DO JULGADOR}

Para finalizar esse breve estudo sobre o grande campo de pesquisa que engloba as Falsas Memórias e suas implicações, deve ser feita uma última análise a uma figura central e controversa no processo penal: o Juiz e sua subjetividade.

Como é sabido, o Juiz na posição de autoridade máxima do processo, tem como dever se manter imparcial frente às partes. O julgador deve postar-se entre as partes e acima delas, como condição de sua função, ${ }^{88}$ adotando condutas que não demonstrem favorecimentos a uma determinada parte em detrimento da outra. Por isso, o Princípio da Imparcialidade é de essencial importância e relevância no Direito, uma vez que controla discriminações e atitudes arbitrárias dos Juízes quanto ao tratamento diferenciado das partes no processo.

A imparcialidade dos Juízes, entretanto, não deve ser tamanha a ponto de cegar os julgadores quanto às desigualdades, dilemas e anseios ocorrentes, da mesma maneira que não deve ser compreendida como a legitimação da total abstenção judicial, a ponto da produção de um resultado injusto no processo. Por isto, discute-se a neutralidade do Juiz, uma vez que um julgador imparcial não necessariamente será um julgador neutro.

Sendo o Julgador um ser humano, é impossível que sejam excluídas no seu ato de julgar suas motivações, suas questões existenciais, suas emoções, sua visão de mundo, bem como seus preconceitos. Por mais distanciado e focado que esteja dos seus instintos, por mais que esteja em postura profissional, o Juiz, no ato de julgar, ainda carrega consigo, projetando no processo, seu eu particular. É o agente social que fala, na posição do profissional; de maneira que seus valores, tradições e costumes, ou seja, toda a sua singularidade que dita os rumos da sentença. ${ }^{89}$

Sabendo que o Julgador carrega e usa seu subjetivismo ao julgar, a avaliação das provas também está sujeita a passar por essa análise interna do Magistrado. Ainda que toda prova usada no processo, ao ser avaliada, deva observar o Princípio do Livre Convencimento Motivado, mitigando a discricionariedade do Juiz ao fazê-la, não há como controlar que esta avaliação seja feita de forma meramente racional, sem ser contaminada pelas vivências, posturas ideológicas, influências e modo de pensar do Julgador, ou seja, pela sua subjetividade.

Posto isto, o subjetivismo do Julgador, também, tem que ser visto como um fator de contaminação da prova testemunhal. ${ }^{90}$ Uma vez que a forma como o Juiz interpreta o caso não é neutra, todo o tipo de informação que venha a ser conhecida por este, seja falsa ou verdadeira, processual ou extraprocessual, que diga algo a respeito do caso julgado, tem potencial de influenciar o modo como decidirá a questão.

tos Forenses. Série Pensando o Direito, Brasília, n. 59, p. 32, 2015.

88 CINTRA, A. C. de A.; DINAMARCO, C. R.; GRINOVER, A. P. Teoria geral do processo. 18. ed. São Paulo: Malheiros, 2002. p. 51-52.

89 GIACOMOLLI, José Nereu; DUARTE, Lisa Bastos. "O mito da neutralidade na motivação das decisões judiciais: aspectos epistemológicos". Revista da AJURIS, v. 33, n. 102, jun. 2006. Disponível em: < http://livepublish.iob.com.br/ntzajuris/lpext.dll/In fobase $/ 1722 \mathrm{f} / 17289 / 17 \mathrm{c} 5 \mathrm{e}$ ?f=templates\&fn=document-frame.htm\&2.0>. Acesso em: 5 set. 2017.

90 DI GESU, Cristina. Prova penal e falsas memórias. 2. ed. Porto Alegre: Livraria do Advogado, 2014. p. 187. 
Por isso, sabendo que vivemos em uma sociedade com altos índices de criminalidade, em que, diariamente, os Julgadores têm de lidar com os mais variados tipos de suspeitos e criminosos, é imprescindível que os Magistrados não se deixem levar pelas aparências, preconceitos e estereótipos ligados a certos tipos de pessoas e certos tipos de crime. Cada caso é único, e assim deve ser visto. Rótulos e apelo social por justiça ocorrem a todo momento e devem ser evitados; bem como a pressão da mídia, em denegrir e ver incriminados determinados suspeitos, não pode ser tomada como formadora de opinião por aqueles que julgaram os casos. Infelizmente, esse cenário não consegue ser totalmente controlado. O Juiz é um ser humano, e não uma "máquina" desprovida de razão e emoção, que consegue se distanciar de todas essas influências. O Juiz, como qualquer Homem, também sente, pensa e se emociona, mas também discrimina e faz pré-julgamentos. Diante disto, na ciência que os crimes contra a dignidade sexual estão dentre os crimes vistos com mais negatividade dentro do nosso meio social, é primordial que o Julgador tenha responsabilidade ao tomar seu posicionamento, não se deixando levar por pressões externas e preconceitos próprios, tentando-se abstrair ao máximo possível dessas influências e avaliando as provas e formando sua decisão com o maior cuidado e calma que conseguir.

Afinal, conforme ao acima exposto, é indispensável que esses mesmos julgadores comecem a rever a forma como o relato testemunhal é avaliado. A ciência da existência das Falsas Memórias e suas implicações por parte do Magistrado faz toda a diferença para a formação de uma sentença mais justa e acurada. Se abster de visões estereotipadas e pré-julgadas para o processo significa muito mais do que ser um ser humano melhor, é se tornar um profissional melhor. Profissional este que tem em seu poder decidir pela verdade e não somente ser levado pela testemunha a um julgamento errôneo.

\section{Considerações finais}

Diante de todo exposto, importa salientar algumas conclusões. Retomando a análise dos crimes contra a dignidade sexual, impera notar que esse tipo criminal, diante da natureza dos delitos que engloba, está suscetível de não ser facilmente comprovado. Os crimes contra a dignidade sexual têm em comum o alto risco de serem consumados sem que deixem rastros materiais, e, mesmo em situações que apresentem vestígios, em regra, esse vestígio se não colhido em tempo hábil perde sua função como prova. Nesse contexto, é senso comum na Justiça casos envolvendo esse tipo de crime serem solucionado com base na palavra testemunhal, a qual em regra trata-se da vítima, uma vez que é frequente esta ser a única presente no momento da agressão sexual.

A palavra da vítima, nesse sentido, adquire importante posição como meio de prova nos crimes contra a dignidade sexual, podendo o Magistrado, por livre escolha, avaliar o peso probatório dela frente às outras provas colhidas para a solução do litígio. O que se percebe é que os Juízes muitas vezes superestimam o relato da vítima em comprometimento de outras evidências trazidas em juízo, haja vista que existe toda uma crença de que uma testemunha de boa reputação, comprometida com a verdade e a justiça e que se mostre firme em seu discurso, não cometeria erros ao descrever os fatos e ao reconhecer os suspeitos.

Essa visão dos fatos não resta verdadeira. A fidedignidade de um relato não depende da intenção do sujeito, de sua personalidade, das suas condutas de vida, tampouco da sua certeza com suas lembranças. A fidedignidade de uma lembrança está muito mais ligada à capacidade de memorização daquele indivíduo, do nível de exposição que esse sujeito teve a sugestões e induções, bem como à quantidade de distorções e falsas lembranças que foram produzidas nesse meio tempo.

O fato de a Justiça se mostrar muitas vezes despreparada para lidar com problemáticas envolvendo a preservação da memória da testemunha é de inestimável peso negativo. As consequências não são simples, tampouco irrelevantes. Os erros relativos a falhas na memória podem culminar em graves acontecimentos: 
não raro a testemunha lembra, distorcidamente, dos fatos ou realiza um falso reconhecimento, o que culmina na prisão de pessoas inocentes e na impunidade dos reais culpados. O problema se intensifica quando se foca no fato de a prova testemunhal ser utilizada como instrumento probatório isolado nos crimes contra a dignidade sexual, e, mesmo assim, devido à falta de conhecimento e cuidado das autoridades jurídicas e policiais, as testemunhas se contaminam e apresentam erros em suas lembranças, comprometendo toda a segurança e justiça do processo.

Por meio dos estudos das falsas memórias descobriu-se muito mais sobre o funcionamento da capacidade de recordação, inclusive, entendendo alguns fatores que levam a distorções e alterações na forma como um evento é recordado. Percebeu-se que as induções podem ser tão fortes a ponto de a pessoa lembrar com alto grau de certeza fatos ou eventos que nunca ocorreram ou que não ocorrem com exatidão daquela maneira, bem como reconhecer erroneamente pessoas, objetos e coisas. Esses estudos demonstraram que diversas condutas realizadas nas entrevistas policiais e judiciais com as vítimas estavam levando estas a criarem falsas memórias. Mais especificamente, a entrevista que era o método utilizado com o propósito de descobrir a verdade, muitas vezes, implicava na destruição de toda a credibilidade e acurácia da prova oral, a qual, em certos casos, é a única prova válida para a solução do litígio.

Com estudo das Falsas Memórias, também, é possível buscar soluções, que, apesar de não solucionarem por completo a problemática, reduzem, expressamente, o nível de danos. Alguns métodos buscam tornar o procedimento realizado nas entrevistas menos intrusivo, dando mais liberdade à testemunha a lembrar-se sozinha dos fatos, sem ser guiada pelo entrevistador e, consequentemente, induzir-se pelas atitudes deste. Além de tantas outras metodologias que buscam contornar os diversos meios de contaminação.

Por isto, no Direito, é fundamental o estudo das Falsas Memórias, com o intuito de se compreender o melhor funcionamento da capacidade de recordação do ser humano, assim como as possíveis falhas e as melhores soluções, a fim de construir um meio jurídico preparado para lidar, adequadamente, com a testemunha e, consequentemente, com a melhor preservação das memórias desta, culminando em resultados mais justos e comprometidos com a verdade..

\section{REFERÊNCIAS}

ALTAVILlA, Enrico. Psicologia judiciária. Tradução de Fernando de Miranda. 2. ed. São Paulo: Livraria Acadêmica Saraiva Editores, 1945. v. 1.

ARANHA, Adalberto José Q. T. de Camargo. Da prova no processo penal. 7. ed. São Paulo: Saraiva, 2006.

BRAINERD, C. J. et al. How does negative emotion induce false memories? Psychological science, v. 19, n. 9, p. 919-925, 2008.

CAPEZ, Fernando. Curso de direito penal. 9. ed. São Paulo: Saraiva, 2011. v. 3.

CÉSPEDES, Lívia; ROCHA, Fabiana da (Org.) Vade mecum. São Paulo: Saraiva, 2017.

CHAN, Jason C. K.; THOMAS, Ayanna K.; BULEVICH, John B. Recalling a witnessed event increases eyewitness suggestibility the reversed testing effect. Psychological Science, v. 20, n. 1, p. 66-73, 2009.

CINTRA, A. C. de A.; DINAMARCO, C. R.; GRINOVER, A. P. Teoria geral do processo. 18. ed. São Paulo: Malheiros, 2002.

CORDERO, Franco. Procedimiento penal. Trad.: Jorge Guerrero. Santa Fé de Bogotá- Colômbia: Editorial Temis, 2000. v. 2.

DAMÁSIO, Antônio. O erro de Descartes: emoção, razão e o cérebro humano. Trad. Dora Vicente e Georgina Segurado. 8. ed. São Paulo: Companhia das Letras, 2001. 
DELMANTO, Celso. Código Penal comentado: acompanhamento de comentários, jurisprudência, súmula em matéria penal e legislação complementar. 8. ed. São Paulo: Saraiva, 2010.

DI GESU, Cristina. Prova penal e falsas memórias. 2. ed. Porto Alegre: Livraria do Advogado, 2014.

FLECH, Larissa Civardi. Falsas memórias no processo penal. Disponível em: <https://www.lume.ufrgs.br/ bitstream/handle/10183/67291/000872494.pdf?sequence=1>. Acesso em: 20 jul. 2017.

GAUER, Ruth. “Falar em tempo, viver o tempo!”. In. GAUER, Ruth M. Chittó; LINHARES, Mozard. (Org). Tempo: história. Curitiba: Juruá, 1999.

GIACOMOLLI, José Nereu; DUARTE, Lisa Bastos. “ O mito da neutralidade na motivação das decisões judiciais: aspectos epistemológicos”. Revista da AJURIS, v. 33, n. 102, jun. 2006. Disponível em: < http:// livepublish.iob.com.br/ntzajuris/lpext.dll/Infobase/1722f/17289/17c5e?f=templates\&fn=document-frame.htm\&2.0>. Acesso em: 5 set. 2017.

GIACOMOLLI, Nereu josé. A fase pre-liminar no processo penal: crises, misérias e novas metodologias investigativas. Rio de Janeiro: Lumen Juris, 2011.

GOULART, Valéria Diez Scarance Fernandes. Tortura e prova no processo penal. São Paulo: Atlas, 2002.

GRECO FILHO, Rogério Greco. Curso de direito penal: parte especial. 10. ed. Rio de Janeiro: Impetus, 2013. v. 3.

INNOCENCE Project. Disponíveis em: <https://www.innocenceproject.org/all-cases/\#involvedyes,exonerated-by-dna,sex-crimes $>$. Acesso em: 31 maio. 2018.

ISHIDA, Válter Kenji. Curso de direito penal. 2. ed. São Paulo: Atlas, 2009.

ISHIDA, Válter Kenji. Processo penal: de acordo com a reforma processual penal. São Paulo: Atlas, 2009. Disponível em: <https://www.passeidireto.com/arquivo/18046231/valter-kenji-ishida---processo-penal--1-edicao---ano-2009>. Acesso em: 10 jul. 2017. p. 113.

IZQUIERDO, I. $A$ arte de esquecer. 2. ed. Rio de Janeiro: Vieira \& Lent, 2009. v. 1.

IZQUIERDO, Ivan. A memória. Entrevisyta com Ivan Izquierdo concedida à RAN - Revista Argentina de Neurociência, por Ignacio Brusco, MD; Diego Golombeck, Phd e Sérgio Strejilevich, MD. Trad. Renato M. E. Sabbatini. Disponível em: <http://www.cerebromente.org.br/n04/opiniao/izquierdo.htm>. Acesso em: 23 jul. 2017.

IZQUIERDO, Iván. Memória. 2. ed. Porto Alegre: Artmed, 2011. Disponível em: <https://books.google.com.br $/$ books?id $=$ DgPLKEvcE5cC\&pg $=$ PA20\&lpg $=$ PA20\&dq $=\mathrm{A}+$ mem $\% \mathrm{C} 3 \% \mathrm{~B} 3 \mathrm{ria}+\mathrm{do}+$ perfume $+\mathrm{da}+$ rosa $+\mathrm{n} \% \mathrm{C} 3 \% \mathrm{~A} 3 \mathrm{o}+$ nos + traz\&source $=$ bl\&ots $=-7 \mathrm{zWKcMeAf \& sig}=1 \mathrm{RsAEb} 4 J \mathrm{JImA}$ 7aag5RGeLR4wxbI\&hl=pt-BR\&sa $=$ X\&ved=0ahUKEwiTs5Sbz5rVAhWJgZAKHQo0BFcQ6AEIJzAA\#v=snippet\&q $=$ trabalho\&f=false $>$. Acesso em: 23 jul. 2017.

IZQUIERDO, Iván. Memória. Porto Alegre: Artmed, Reimpressão, 2006.

KENSINGER, E. A., \& SHACTER, D. L. When the red sox shocked the yankees: comparing negative and positive memories. Psychonomic Bulletin \& Review, v. 13, n. 5, p. 757-763, 2006.

KIHLSTROM, J. F. Exhumed memory. New York: Guilford, 1998.

LOFTUS, Elizabeth. “As falsas lembranças”. Revista Viver Mente \& Cérebro, p. 90-93, 2005.

LOPES JUNIOR, Aury. Direito processual penal e sua conformidade constitucional. 4. ed. Rio de Janeiro: Lúmen Júris, 2009. v. 1.

LOPES JÚNIOR, Aury. Direito processual penal e sua conformidade constitucional. 8. ed. Porto Alegre: Lumen Juris, 2011. v.1. 
MALATESTA, Nicola Framarino Dei. A lógica das provas em matéria criminal. Trad.: Paolo Capitanio. Campinas: Bookseller, 2004.

MUCCIO, Hidejalma. Curso de processo penal. 2. ed. Rio de Janeiro: Método, 2011.

NEUFELD, Carmem Beatriz; BRUST, Priscila Goergen; STEIN, Lilian Milnitsky. Compreendendo o Fenômeno das Falsas Memórias. In: STEIN, Lilian Milnitsky; et. al. Falsas memórias: fundamentos científicos e suas aplicações clínicas e jurídicas. Porto Alegre: Artmed, 2010. p. 21-41.

NEWS, CBN. Exclusive: The bunny effect. Youtube, 8 mar. 2009. Disponível em: $<$ https://www.youtube. com/watch?v=eZlPzSeUDDw>. Acesso em: 29 jul. 2017.

NUCCI, Guilherme de Souza. Código de Processo Penal comentado. 13. ed. Rio de Janeiro: Forense, 2014. Disponível em: <http://sta.pro.br/livros/19\%20-\%20NUCCI_Guilherme_de_Souza_C\%C3\%B3digo_de_ Processo_Penal_Comentado_2014.pdf>. Acesso em: 10 jul. 2017.

NUCCI, Guilherme de Souza. Código de Processo Penal comentado. 8. ed. São Paulo: Revista dos Tribunais, 2008.

RODRIGUES, Horácio Wanderlei. Acesso à Justiça e prazo razoável na prestação jurisdicional. In: WAMBIER, Teresa Arruda Alvin (Org.). Reforma do Judiciário: primeiras reflexões sobre a emenda constitucional n. 45/2004. São Paulo: Revista dos Tribunais, 2005.

ROEDIGER, Henry L.; KARPICKE, Jeffrey D. Test-enhanced learning taking memory tests improves long-term retention. Psychological Science, v. 17, n. 3, p. 249-255, 2006.

SCHACTER, Daniel. Os sete pecados da memória: como a mente esquece e lembra. Rio de Janeiro: Rocco, 2003.

SILVA, Queli Cristiane Schiefelbein da; SPENGLER, Fabiana Marion. Memória e Tempo: a razoável Duração do Processo Pós-Emenda Constitucional no 45/2004. Direito em Debate: Revista do Departamento de Ciências Jurídicas e Sociais da Unijuí, Rio Grande do Sul, v. 12, n. 39, p. 99-121, 2013.

SPENGLER, Fabiana Marion. Da jurisdição à mediação: por uma outra cultura no tratamento de conflitos. Ijuí: Unijuí, 2010.

STEIN, Lilian M. Avanços Científicos em Psicologia do Testemunho Aplicados ao Reconhecimento Pessoal e aos Depoimentos Forenses. Série Pensando o Direito, Brasília, n. 59, 2015.

STEIN, Lilian M. et al. "Memória, humor e emoção”. Revista de Psiquiatria, Rio Grande do Sul, v. 28, n. 1, p. 66-68, 2006. Disponível em: <http://www.scielo.br/scielo.php?script=sci_arttext\&pid =S0101-81082006000100008>. Acesso em: 8 set. 2017.

STERNBERG, R. J. Psicologia cognitiva. Porto Alegre: Artes Médicas Sul, 2000.

TOURINHO FILHO, Fernando da Costa. Processo penal. 30. ed. São Paulo: Saraiva, 2008. v. 3.

TUCCI, José Rogério Cruz e. Tempo e processo: uma análise empírica das repercussões do tempo na fenomenologia processual (civil e penal). São Paulo: Revista dos Tribunais, 1997.

VIRILIO, Paul. "O paradoxo da memória do presente na era cibernética”. Entrevista com Paul Virilio concedida a Frederico Casalegno. In: Memória cotidiana: comunidades e comunicação na era das redes. Entrevista com Paul Virilio concedida a Frederico Casalegno. CASALEGNO, Frederico. Memória cotidiana: comunidades e comunicação na era das redes. Trad. de Adriana Amaral, Francisco Rüdger e Sandra Montardo. Porto Alegre: Sulina, 2006. 
Para publicar na revista Brasileira de Políticas Públicas, acesse o endereço eletrônico www.rbpp.uniceub.br

Observe as normas de publicação, para facilitar e agilizar o trabalho de edição. 